\title{
A systematic frame work of schedule risk management for power grid engineering projects, sustainable development
}

\author{
Wajiha Ansari \\ MBA Student Karachi University Business School, University of Karachi Pakistan \\ wajihaansari13@gmail.com \\ Muhammad Asim \\ Chairperson Karachi University Business School, University of Karachi, Pakistan \\ Salman Manzoor \\ Education and Literacy Department, Government of Sindh, Pakistan
}

\begin{abstract}
Design dangers are the key risk for extraordinary viability of timetable organization in (PGEP). This paper intends to manufacture a methodically system for design RM, which comprises of three measurements, including the work force measurement, technique measurement and time measurement, explicitly supervisory faculty, the executives strategies and the development procedure, consistently. Responsibilities of staff with different capacities are examined in the supervisory faculty part, and six phases and their concurring 40 key works are guaranteed as the time measurement. RI, assessment, appraisal and expectation together framed the technique measurement. In view of this foundation, 222 planned dangers happen in the entire procedure of PGEPs are distinguished through questionnaires and interviews. At that point, the connection among each hazard is made sense of dependent on the Interpretative Structure Model (ISM) technique and the effect of each hazard is quantitatively surveyed by setting up assessment framework. The genuine act of the planned system is checked through the investigation of the primary phase of a PGEP. At long last, the outcomes show that this structure of planned RM is significant for refining the productivity of PM. It gives administrators a more clear methodology with which to lead RM encourages them to opportune recognize chances and keep dangers from happening. It is likewise simple for administrators to pass judgment on the impact level of each hazard, so they can take activities dependent on the degree of each hazard's seriousness. Generally speaking, it is gainful for power lattice endeavours to accomplish a feasible administration.
\end{abstract}

Keywords. power grid engineering project; schedule management; risk management; Interpretative Structure Model; Analytic Hierarchy Process 


\section{Introduction}

Risk is an undefined occurrence or situation that, if it happens, has a progressive or a bad consequence on a task objective. Risk Management (RM) is the organized procedure of recognizing, investigating, and answering to task threat. RM comprises of exploiting the likelihood and significances of optimistic proceedings and reducing the likelihood and significances of argumentative proceedings to task objectives. Task management is the presentation of information, expertise, gears, and methods to task accomplishments in order to come across or surpass investor prerequisites and prospects from a task.

Project hazard control is an essential a part of every task-driven association (Cano and Cruz, 2002). While the level of superiority, the possibility of the evaluation, or even the language classification of the approaches vary drastically across enterprise sections, certainly all irreparable useful source obligation choices comprise a few amount of ambiguity and threat. Though, even inside an association, specific practices are advanced for extraordinary functions. Typical effort strategies for considered, task, or challenge operations chance analysis may additionally be quite exceptional and in large part separated from one to the other. As a consequence, the technique to threat management frequently converts narrow-minded and in particularly centred on acquiescence, (i.e. gathering the danger receiving standards from an administrative standpoint or ducking any non-public publicity from the work task perception). This point of view is inconsistent to the advanced goal of task danger management that may be a organized method to help make complete choices about matching between the planned risks and the expenses of justification.

The ultimate problem in growing extra vertically combined threat control practices is that the significances can't be without problems captured the use of a single portion. For example, threat influences will be clear in phrases of fee increase, interruption, substantial accessibility, or occurrences, which replicate extraordinary strategic targets for diverse processes (Garvey, 2009). As these are very extraordinary measures, the operative evaluation often turns into disjointed and basic to consciousness at the key targets. This explanation comes with the value of dropping the "influence arrangement", which delivers essential visions into how the dangers have an effect on the processes and one another. Once these explanations are vanished, the dependencies may simplest be counted using statistical or independent processes of correspondence; however those approaches do not longer openly account for the common sense of the hazard impact structure.

As a consequence of macro-economic panels, the increase charge of national energy request hang onto developing in Pakistan. The yearly making potential of energy went up to over $45,000 \mathrm{kWh}$ in 2011, almost three instances of that in 2002. The progress proportion of power manufacturing in every 12 months set aside encouraging as well. It is predicted that the entire energy intake will develop at a yearly increase proportion of $7.8 \%$ at some stage in the "twelfth Five-Year Plan" era (2011-2015), in an effort to be greater than $6 \times 1012 \mathrm{kWh}$ in 2015 . Furthermore, the twelve-monthly developing percentage might be $6.1 \%$ for the duration of the "thirteenth Five-Year Plan" retro, and the entire number will grasp closely $8.2 \times 1012 \mathrm{kWh}$ in 2020. The quantity of immovable asset funding in power and high temperature creation and source engineering performed 4762 billion in 2011, at an yearbook typical development proportion of $14.2 \%$ within the previous 7 years. 
Consequently, the quantities of power grid engineering projects (PGEPs) will be prolonged. Diverse from fashionable tasks, PGEPs are capable with much individuality, such as excessive cost, multifaceted expertise, hundreds of sections involved, tight time table requests, extended building sequence, complicated production environment and different features. All these govern that the production procedure of a PGEP is challenge to a number of risky dynamics, which results in clean happening of dangers. Schedule dangers are recognized as dangers whose look would cause the extension of challenge's lifecycle. Excluding for task period's increasing, this form of danger also reasons a full-size upsurge of challenge costs, strategy variations, lessening of the efficiency and competence of business administration and so on.

Currently, the power grid marketplace is specifically engaged by groups in Pakistan, namely the NTDC and MATIARI Corporation. However, the Enterprise Resource Planning (ERP) system, a quite incorporated system, masking business, tasks and strategies, is broadly carried out in these power grid corporations, evidence interrelated to schedule threat management isn't enclosed.

Thus, if there have been no analytically programmed danger control outline seeing administrative arrangement, creation section and workflow for these businesses, they would simply grieve damages as a consequence of schedule risks. As a consequence, it is important to ponder on a diversity of planned dangers at some point of a PGEP's production course.

The Karachi Electric Supply Company (KESC), an incorporated power generation and source corporation, needs to become stable and naturalize its broadcast and circulation system and Damage lessening plug-in by adding spotless and additional energy effective gas fired up mutual cycle components at its current power plants on fast trail basis and improvement and assimilates its current broadcast and circulation possessions in order to overwhelmed the energy damages. The T\&D reintegration will include the replacement of towers, cables, reintegration of broadcast outlines, and instalment of new grid stations and building of new overhead and subversive broadcast lines. The planned task is part of this reintegration and up gradation program.

This study objects to shape an organized schedule hazard control context for PGEPs' sustainability. A writings review is accompanied within the concluding part of Unit 1 . The framework is recommend and discoursed in Unit 2, that's a three-D structure primarily based on 3 facets, including control workers, building method and administration practices. Additional, the study suggests the manoeuvre procedure of the projected context and intensely examines the schedule danger all through the construction process in Section 3. With particular case observe in feasibility examine level; the first degree of PGEP building, the paper confirms the possibility of the recognized context. Eventually, Unit 4 completes this study.

\section{Literature review:}

\section{Background of study:}

Task hazard control is the procedure of recognizing, examining, and justifying task dangers (ISO, 2009). Certain threat identification and valuation methods are information concentrated, even as others trust on elicitation of specialists' beliefs. Risk demonstration additionally takes unique forms, fluctuating from danger grounds with dangers classified into graded classifications (i.e., extraordinary, medium, stumpy opportunity/impression), to greater 
targeted and measurable approaches inclusive of error and occasion tree examination, approximation of possibility distributions, and standardization of statistical models. Therefore, justification and control strategies vary as well, subsequent to the tactics accepted in the preceding stages of the whole procedure.

Shen L Y (1997) recognized the furthermost thoughtful undertaking postponement risks and the actual moves for dealing with these dangers. Specialists' chance control moves and their efficiency had been examined via a questionnaire review. It discovered that approaches wherever experts' knowledge and particular decision are used are the only and essential chance control action, and that approaches consuming measurable analytical practices were hardly used because of incomplete know-how and revel in. The conclusions also endorse a need to endorse the software and consciousness of numerous investigative methods for chance administration in a appropriate background inside the Hong Kong production business.

Further research in 1999 classified the danger elements and their justifying procedures, the greatest active threat justifying procedures had been characterized into 8 groups. Those are companion collection, settlement, occupation, mechanism, authorizing, manufacturing agreement, true association, and renegotiation. They projected a danger management version integrating procedures. Three circumstances of global creation JVs had been investigated from the viewpoints of the implementation of these procedures.

Thomas et al (2003) carried out risk belief analysis to evaluate the danger criticality, hazard control capability, hazard provision/distribution inclination, and features prompting hazard popularity of foremost investors in BOT projects. They plotted diverse senior challenge contributors such as management executives, sponsors, creditors and advisers of BOT tasks. Eight forms of dangers have been recognized as very serious within the Indian avenue division under BOT system with road traffic income danger being the most essential. The research discovered that the features and their comparative effect on the danger reputation of investors are notably diverse.

Renuka et al., (2014) provide an explanation for infrastructure improvement will upsurge the development of republics financial system and produces the huge amount of work prospects. Hence those tasks contain a huge quantity of asset to carry out. In outlook of that, if any kind of waste (both time, assets etc.) happens that would lead to the big financial fatalities. These damages happen due to numerous dangers linked with such extra-large tasks. Subsequently, these dangers play an essential position for the achievement of task in the time planned and intended budget. In this association, this research particularly deliberates the vital danger elements and its valuation strategies thru proportional research of diverse global construction tasks. About 50 applicable articles available over the last 25 years have been studied. The evaluation stemmed that a humble investigative device might be established for each task mission to measure the chance effortlessly and quickly, so that you can inspire the specialists to do the risk examination in their task.

Task Risk Management (RM) was no longer a vital element of venture control until the cease of the 1970s. For danger control manner, a huge figure of investigators has suggested several opinions. Chapman provided Task Risk Examination and Administration (PRAM) system, which blanketed the important factors of task administration and recognized techniques and strategies of examination for the task's dangers in a revolutionary manner. The Institution of RM clear the RM System (RMS), and defined the establishment of dangers and danger stages 
and distributed RMS into 5 chunks, counting danger source, danger features, threat valuation, chance manage and post-assessment. The Task Administration Institution projected the Task Administration Form of Understanding PMBOK, which concise the course of RM as containing 6 stages, specifically hazard control plan, danger identification, qualitative threat valuation, measurable threat approximation, risk comeback strategies and hazard control. On the whole, actual RM includes a four-phase system, founding risk identification, threat examination, chance assessment and threat reaction.

The quantity of dangers essential in the power grid task is tremendously huge, so danger identity needs hazard class first. Certain strategies for type have been recommended in previous researches. For instances, a few investigators targeted on the danger source and a few focused on the categorized connection among dangers.

For threat examination, specific researchers have targeted on various investigative objectives. Liu examined non-additive influences below the have an effect on of manifold dangers and put courtesy to the association amongst numerous dangers. Furthermore, few other investigators centred on the bond association among threats. Additionally, an extensive variety of approaches could be used to efficiently carry out threat examination, including Fault Tree Examination, Sensitivity Examination, Approximation of Structure Dependability and Outcome Examination, Uncertain group, Bayesian systems and others.

Numerous techniques had been accepted for measuring task dangers. At first, various researchers executed statistical techniques to deal with the planned danger and progressively, many determined that social features, expert knowledge and private finding were crucial for risk assessment. Furthermore, the signs used to assess the threats can be concise as probability, disclosure, manageability and controllability inside the preceding writings, and threat value has been used as an significant danger effect size as well. Additionally, assorted simulations might be exploited intended for danger valuation. It is obvious that AHP, established through Thomas has acknowledged a global gratitude. It is an actual as well as systematically technique designed for measuring effect of dangers plus assigning effect weight and plenty of investigators have tested it.

Among the departing investigation, certain recognition on task time table controlling, and a few place stresses on risk control. Though, investigators rarely give attention to PGEPs, time table supervision and risk control collectively. Furthermore, the modern-day hazard management of engineering tasks grants dispersed eye in Pakistan, this means that supervisors rarely recollect hazard control from an incorporated opinion. For instance, supervisors continuously focus on the considerable dangers, whereas miss the ones which possess stumpy occurrence or slight influence, it is common to hint the threat duty after coincidence happening as an alternative of earlier. Under those conditions, decision-making nonconformities and neglects without difficulty occur, which make a contribution to remarkable damages. Consequently, it's miles quintessential to perform complete identification, satisfactory examination and systematic prevention of planned dangers.

The concept of risk $(R)$ :

$\mathrm{R}$ is the probable for unrestrained damage of somewhat of worth. Standards (such as physical health, communal prestige, sensitive comfort, or monetary prosperity) can be extended or vanished when captivating danger follow-on from a assumed deed or indecision, predicted 
or unexpected (intentional or not intentional). Danger can also be distinct as the deliberate collaboration with ambiguity. Doubt is a probable, random, and uncontainable conclusion; danger is a feature of achievement occupied in spite of ambiguity.

\section{Risk management (RM) concept:}

$\mathrm{RM}$ is the practice of recognizing, calculating and observing fears to an administration's investment as well as remunerations. These fears, or else threats, might stem from an widespread collection of fundamentals, including economic insecurity, lawful obligations, planned administration mistakes, coincidences and ordinary calamities. IT sanctuary fears and data-related dangers, and the RM approaches to lighten them, have turn out to be a topmost significance for digitized businesses. Consequently, a RM approach increasingly encompasses industries' procedures intended for recognizing as well as monitoring fears to its digital personal effects, including high-class corporate numbers, a customer's personally identifiable information (PII) and intelligent possessions.

Each corporation and association faces the threat of unanticipated, damaging events that can charge the business money or source it to perpetually close. RM permits administrations to endeavour to make for the unanticipated by diminishing dangers and additional expenses in advance they occur.

\section{Importance of risk management:}

Through executing a RM strategy and bearing in mind the numerous probable dangers or proceedings in advance they happen, an association can save currency and defend their upcoming. This is for the reasons that a vigorous RM strategy will benefit a business institute measures to sidestep probable fears, reduce their influence should they happen and manage with the fallouts. This capability to comprehend and control danger will permit administrations to feel supplementary assured about their corporate judgments. Additionally, robust business supremacy philosophies that emphasis precisely on RM can benefit a business grasp their objectives.

The significance of merging RM with enduring protection has also been exposed. In utmost hospitals and administrations, the RM and enduring protection branches are divided, they integrate diverse governance, objectives and opportunity. Conversely, certain hospitals are distinguishing that the capability to deliver harmless, superior enduring precaution is essential to the defence of monetary possessions and, consequently, should be integrated with RM.

In 2006, the Virginia Mason Medical Centre in Seattle, Washington incorporated their RM tasks into their enduring protection division; eventually generating the Virginia Mason Production System (VMPS) administration approaches which emphasis on constantly refining the enduring protection structure by growing transparency in risk justification, discovery and writing. Meanwhile executing this new structure, Virginia Mason has practiced a noteworthy decrease in hospital specialized perks and a great upsurge in the writing philosophy.

\section{Why is risk management important to project success?}

Real RM policies permit you to recognize your task's strong point, dimness, prospects and intimidations. By scheduling for unanticipated proceedings, you can be prepared to answer back if they stand up. To guarantee your task's achievement, describe how you will grip 
probable threats so you can recognize, alleviate or sidestep glitches when you require doing. Fruitful task bosses identify that RM is significant, since accomplishing a task's objectives rest on on scheduling, groundwork, outcomes and assessment that underwrite to attaining planned goal line.

\section{Planning for success:}

RM strategies underwrite to task achievement by founding a list of core and outside threats. This strategy characteristically comprises the recognised dangers, likelihood of happening, probable influence and planned activities. Squat threat proceedings typically have slight or no influence on price, plan or enactment. Reasonable threat reasons certain upsurge in price, interruption of plan or humiliation of enactment. Extraordinary threat proceedings are probable to reason a noteworthy upsurge in the budget, interruption of the plan or performance glitches.

\section{Communicating with stakeholders:}

To confirm that tasks course effortlessly, actual task bosses interconnect their strategy to the task promoters, investors and squad associates. This arrays prospects to persons who arrange for finance and are exaggerated by the consequences. It confirms that the task goes efficiently so one phase continues to the next without disturbance. By recognizing, sidestepping and distributing with probable threats in progress, you confirm that your workers can answer back successfully when trials appear and oblige involvement.

\section{Maximizes results and meet deadlines:}

By means of outlining RM procedures for your business, you mark achievement additional probable by decreasing and removing undesirable threats so tasks can be completed on time. This permits you to come across your budget and accomplish directed purposes. When you don't have RM approaches in place, your tasks get uncovered to glitches and turn out to be susceptible. In effect RM approaches permit your business to exploit earnings and reduce expenditures on happenings that don't create a reoccurrence on outlay. Over and done with comprehensive investigation, operative influential line up continuing work grounded on the marks shaped, in spite of the probabilities.

\section{Be proactive not reactive:}

Taking a RM strategy in place permit you to be taking the initiative and yield footsteps to alleviate conceivable troubles in advance they get to your feet, as an alternative of continuously fire struggling. The task line-up can take the danger that have been recognized and transform them to actionable stages that will decrease probability. Those stages then turn out to be possibility strategies that confidently can be sideways. Must a danger incident happen, the likelihood strategy can be whipped out rapidly, dropping the lost time on a task.

\section{Evaluates the entire project:}

To assess your task's achievement so you can use the finest practices on your subsequent task, evaluate the influence of your accomplishments on justifying experience to glitches and take advantage of prospects that exploit on your business's strong point. For 
instance, if you grow and distribute a preparation program that makes consciousness about internet safety, counting phishing, Trojan horse and individuality robbery, measure the number of support desk calls acknowledged about these glitches. If they fall, you can sensibly take up your RM resourcefulness have underwrote to achievement. If not, review your preparation program.

\section{The framework of schedule risk management:}

In edict toward marking planned RM more widespread, a 3-dimensional context is recognized. This agenda considers three significant elements in PGEPs, specifically persons, time and administration techniques, that are controlling workers, production degrees as well as chance supervision techniques correspondingly.

Figure 4: Schedule risk management framework:

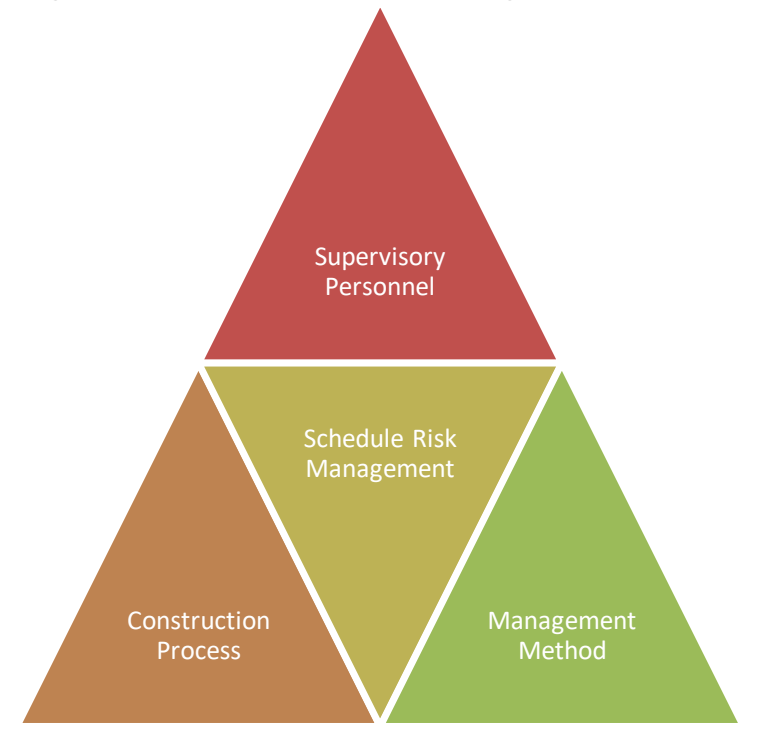

In the NTDC and MAITAIRI Corporation, the administrative shape is self-possessed of headquarter, the regional and the urban stage subordinate businesses. The PGEPs need to remain central as well as accepted by means of using head office each time, formerly spread out in the direction of regional groups. Ultimately, urban degree holdings are accountable intended for execution. Workers in those two groups effort as owners, also, inventors, suppliers and managers are very significant in PEGPs as well. More information is mentioned in Section 2.1 .

In accord with the overall system of partition in task administration, the procedure incorporates six phases, specifically Possibility learning level, Initial strategy level, education level, Creation level, and Achievement and acceptance degree and assessed degree. Additional, each degree includes numerous important workings that are completely deliberated in Unit 2.2. Hazard control sequence is typically distributed into 4 portions, specifically risk identification (RI), risk analysis (RA), threat estimation (RE) and hazard comeback (RR). Pertinent information is deliberated in Unit 2.3. Each boss desires towards sensibly recognize, examine besides avert the probable threats at each level as well as each effort in the course of the development course. The gratified of the threats on this background maintains informing after 
all PGEP, and this structure by means of a manual paperback intended for each boss, that enables them to choose the influence of each danger, avert dangers and resist threats. Consequently, a comprehensible threat coping with framework has been moulded.

\section{Administrative workforces:}

Usually, the individuals of a PGEP complete owners, creators, suppliers and managers. The control concerns perform the function of owners, whose danger obligation takes the entire method as of task endorsement to post-venture assessment. The creator's duty specifically establishes in expertise the usage of novel resources and novel methods, presenting affordable practical explanations as well as whole project papers, and being capability to meet promised requirements. The main suggests of suppliers' obligation are imparting balanced coaching of making strategies and creation packages, being appropriate venture bosses and technical specialists, being well in on to protection consciousness, and correctly succeeding production requirement necessities. Main demonstrations of managers include offering well reviews about supplier's unlawful actions, having competent capacity and a good manipulate of applied knowledge and imparting adequate expert livelihood.

\section{Construction process:}

This research splits creation mode of PGEPs into 6 levels as detailed overhead. Additional, each phase is consisting of numerous key mechanisms, which can be the marks inside the planned control. The postponement of these efforts will carry undesirable influences going on sequel mechanism as well as finally make bigger the full time restriction of the task. Forty main mechanisms are decided over and done by visiting 12 specialists of task administration as well as proven in Table 1.

\begin{tabular}{|c|c|c|c|}
\hline Stage & Key works & Stage & Key works \\
\hline \multirow{5}{*}{$\begin{array}{l}\text { A } \\
\text { Feasibilit } \\
\text { y } \\
\text { study } \\
\text { stage }\end{array}$} & $W_{l}$ Grounding of task offers & \multirow{5}{*}{$\begin{array}{l}\text { B } \\
\text { Prelimina } \\
\text { ry } \\
\text { design } \\
\text { stage }\end{array}$} & $W_{7}$ Enterprise tender \\
\hline & $W_{2}$ Task probability learning & & $W_{8}$ Manufacture units appointed \\
\hline & \multirow{2}{*}{$\begin{array}{l}W_{3} \text { Groundwork of task } \\
\text { probability } \\
\text { studv report }\end{array}$} & & $W_{9}$ Creation of possessor task \\
\hline & & & Department \\
\hline & $W_{4}$ Task possibility valuation & & $\begin{array}{l}W_{10} \text { Conclusion of pre-planning } \\
\text { documents }\end{array}$ \\
\hline \multirow{5}{*}{$\begin{array}{l}\text { C } \\
\text { Construct } \\
\text { ion } \\
\text { preparati } \\
\text { on }\end{array}$} & $W_{5}$ Project Approval & \multirow{5}{*}{$\begin{array}{l}\text { D } \\
\text { Construct } \\
\text { ion } \\
\text { stage }\end{array}$} & $W_{11}$ Preliminary Design \\
\hline & $W_{6}$ Feasibility study approved & & $\begin{array}{l}W_{12} \text { Assessment of introductory } \\
\text { Proposal }\end{array}$ \\
\hline & $W_{13}$ Issued annual plan & & $W_{23}$ Starting Report application \\
\hline & $\begin{array}{l}W_{14} \text { Material and non-material } \\
\text { bidding }\end{array}$ & & $W_{24}$ Start \\
\hline & $W_{15}$ Contact signed & & $\begin{array}{l}W_{25} \text { Safety and quality supervision } \\
\text { of the }\end{array}$ \\
\hline
\end{tabular}




\begin{tabular}{|c|c|c|c|}
\hline \multirow[t]{10}{*}{ stage } & \multicolumn{2}{|l|}{$\begin{array}{l}W_{16} \text { Endorsement of preliminary } \\
\text { project }\end{array}$} & production process \\
\hline & $\begin{array}{l}W_{17} \text { Resources demand planning } \\
\text { and distribution }\end{array}$ & & \multirow[t]{2}{*}{$W_{26}$ Project meetings } \\
\hline & \multirow{2}{*}{\multicolumn{2}{|c|}{$\begin{array}{l}W_{18} \text { Achievement of creation } \\
\text { permits }\end{array}$}} & \\
\hline & & & $\begin{array}{l}W_{28} \quad \text { Foundation construction } \\
\text { acceptance }\end{array}$ \\
\hline & $W_{19}$ Creation drawing proposal & & and handover \\
\hline & \multicolumn{2}{|l|}{$\begin{array}{l}W_{20} \text { Assessment of creation } \\
\text { illustrations }\end{array}$} & $W_{29}$ Process Conversion \\
\hline & \multicolumn{2}{|l|}{ and design handover } & $W_{30}$ Installation project \\
\hline & \multicolumn{2}{|l|}{$W_{2 I}$ Land expropriation } & $W_{31}$ System Debug \\
\hline & \multicolumn{2}{|l|}{$\begin{array}{l}W_{22} \text { Connected waterways, } \\
\text { circuits, }\end{array}$} & $W_{32}$ Supervision Acceptance \\
\hline & \multicolumn{2}{|l|}{ roads and other } & \multirow{2}{*}{$\begin{array}{l}W_{36} \text { Financial completion of } \\
\text { settlement }\end{array}$} \\
\hline $\mathrm{E}$ & $\begin{array}{l}W_{33} \text { Completion of the project } \\
\text { pre- }\end{array}$ & $\mathrm{F}$ & \\
\hline \multirow{3}{*}{$\begin{array}{l}\text { Completi } \\
\text { on } \\
\text { and } \\
\text { acceptan } \\
\text { ce }\end{array}$} & acceptance & \multirow{3}{*}{$\begin{array}{l}\text { Appraise } \\
\text { d } \\
\text { stage }\end{array}$} & $\begin{array}{l}W_{37} \text { Financial completion of final } \\
\text { accounts }\end{array}$ \\
\hline & \multirow{2}{*}{$W_{35}$ Project data compilation and } & & $W_{38}$ Standard production acceptance \\
\hline & & & $W_{39}$ Project Auditing \\
\hline stage & archiving & & $W_{40}$ Project appraised \\
\hline
\end{tabular}

Where, $W i$ is the number of key works, $i=1,2,3, \ldots, 40$.

\section{Administration process:}

Risk identification (RI):

Planned RI is to discover as well as classify numerous dangers that could have an consequence on the time table strategy of initiatives as well as manuscript these dangers. Usually, the effect of RI is a gradient of dangers. Danger foundation identity is an imperative slice of threat identity, which comprises threat possessions recognition as well as danger accountability identification.

\section{Risk property identification:}

In this study, threat possessions might be unevenly distributed in 8 types, counting natural risk (NR), economic risk (ER), financial risk (FR), social risk (SR), management risk (MR), technical risk (TR), policy-legal risk (PLR) as well as environmental risk (EnR).

NRs are those produced by variation of weather, geology, surroundings and additional features. It mostly contains underground eruption, storms, geological tragedies and other power majeure as well as squalls, overflows, snowfall and supplementary stark climate circumstances.

ERs are those rise up from task exterior financial ecological variations or inner financial relative adjustments, such as marketplace prediction blunders, variations in national stock, variations in withdrawal and cash procedures, funding problems, cash flow problems, 
interest rate variations, forex variations, price increases, an irrational monetary shape and others. Public dangers are those instigated through the common unpredictability or variations of common values and conducts, for example dangers of robbery as well as folks' battle.

FRs is those initiated by the shortage of reserve or the extremeness of funding budget, which will lead to the funding interruption and task interject.

MRs are those get up from let-downs of scheduling, association, harmonization, control or other administration mechanism, such as employees dangers, sub-contracting dangers, information transference dangers and treaty dangers.

TRs are those spawned by variations due to expertise's progression, consistency, applicability and obtainability, which may lead to a poorer exploitation of creation ability, an enlarged working rate and a disappointment of the excellence prospects, such as ecological consideration dangers, strategy dangers and creation knowledge dangers.

PLRs are those instigated by foremost variations in politically aware and financial circumstances or in supervision strategies, which will lead to a disappointment of attaining task's goal.

ERs are those carried by variations in community circumstances and ecological influences adjoining the task, which will lead to a task's interruption or discontinue.

\section{Risk responsibility identification (RRI):}

RRI is primarily castoff to recognize the workers who must tolerate the threat if a coincidence happened. Usually, there are four accountable revelries distributing losses from dangers, counting owners, creators, suppliers and managers as specified above.

\section{Risk analysis (RA):}

RA is a slice of the threat administration method for every task, which correspondingly recognizes probable concerns and undesirable influences grounded totally on the statistics of (RI). In a PGEP, it is apparent that the advent of one sort of chance will frequently validate the happening chance of different one or more dangers. From this viewpoint, RA ambitions to investigate the connection of planned risks in PGEPs and create a planned danger pyramid illustration primarily grounded on ISM (Interpretative Structure Modelling) Approach. ISM approach is an investigative system extensively castoff in the up-to-date device industrial that may crumble a multifaceted structure hooked on numerous subsystem fundamentals as well as eventually practice a multi-level categorized arrangement grounded on real-world expertise as well as PCs. It is particularly appropriate for examining abundant elements and a multifaceted association. Comprehensive system is mentioned in Unit 3.2.

\section{Risk evaluation ( $R E)$ :}

$\mathrm{RE}$ is apprehensive by evaluating the threat influence quantitatively conferring to the significances of risk existence. It systematically reflects the likelihood of existence and degree of fatalities of each risk grounded on the (RI) and (RA). To conduct a (RE) constantly prerequisite to shape an evaluation index system and put on systematic approaches, eventually acquire the assessment outcomes. The comprehensive assessment method is revealed in Unit 3.3 . 


\section{Risk prevention (RP):}

(RI), (RA) and risk valuation are significant changeovers to perform more suitable (RP) processes. (RP) is an enormously noteworthy feature of (RM), as well as correspondingly a vital portion of attaining the complete mechanism of the development. Just before efficiently initiate (RP), individual constantly devours to practice a gradient of deterrence procedures, which benefits bosses to stop dangers in advance and monitor undesirable influences when threats happen in interval.

\section{Findings and results:}

Tangible preparation of planned (rm) structure:

The background of plan RM is collected of 3 parts, to be precise, administrative workers, creation method and administration technique. This unit express the association between these 3 portions and stretches an order for bosses about how to control conferring to the background. To be more vibrant and rational, this unit will demeanour the examination subsequent the edict of RM development.

\section{Risk identification (RI):}

By feedback form and discussions, whose defendants embrace task administrators, managers, creators and creation workers, we've got known a complete of 222 threats that happen within the entire method of PGEPs. These dangers likewise are obtained from a large vary of writings together with paper articles and volumes. The number of dangers in every phase and every effort are calculated (Figure 6) and also the exact contented of each threat is showed within the Appendix Table A1. Supported Unit, 222 threats and their consistent qualities square measure established (Table 2, an illustration of practicable Learning Phase).

\section{Risk analysis (RA):}

\section{Arrangement of threat set:}

$R$ could be a PGEP plan threat category. $R I$ is that the style of a threat, $R=(R 1, R 2 \ldots$ R8), R1 is NR, R2 is ER, R3 is $\mathrm{SR}, \mathrm{R} 4$ is FR, R5 is PR, R6 is TR, R7 is MR, and R8 is ER. Supported the relevant specialists' opinions among the business, the common impact between dangers is examined and therefore the connexion medium is achieved. During this paper, there's a solely undesirable impact of a threat occurring. Once a threat occurs, it will solely raise the chance of ulterior threats, rather than averting them (see the appendix for Figure 6 related to risks keyword node in each level). Refer to Table 2 in the appendix for RI and Threat possessions in the Probability learning phase.

Finding of threat significance:

of

By the correlation background, association significance $\square$ exists in accord by means

$$
\quad \mathbf{\quad} \quad \mathbf{R}_{\mathrm{i}} \text { takes not any straight effect on } \mathrm{R}_{\mathrm{j}}
$$

$1 \quad \mathbf{R j}$ puts straight effect on $\mathrm{R}_{\mathbf{j}}$ 
Formerly the Boolean medium $A$ of the numerous threat features $R i$ is deep-rooted.

\section{The formation of reachability surrounding substance:}

Reachability surrounding substance $M \square(I \square A)^{n} \square I \square A \square A^{2} \square \ldots \square A^{n}$

Formerly the reachability surrounding substance $M$ is achieved a

$$
\mathbf{M}=\left[\begin{array}{llllllll}
\hline \mathbf{1} & \mathbf{0} & \mathbf{1} & \mathbf{0} & \mathbf{0} & \mathbf{1} & \mathbf{1} & \mathbf{1} \\
\hline \mathbf{0} & 1 & 1 & 1 & 0 & 0 & 1 & 1 \\
\mathbf{0} & 0 & 1 & 0 & 0 & 0 & 1 & 1 \\
\mathbf{0} & 1 & 1 & 1 & 0 & 0 & 1 & 1 \\
\mathbf{0} & 1 & 1 & 1 & 1 & 1 & 1 & 1 \\
\mathbf{0} & 0 & 1 & 0 & 0 & 1 & 1 & 1 \\
\mathbf{0} & 0 & 0 & 0 & 0 & 0 & 1 & 1 \\
\mathbf{0} & 0 & 0 & 0 & 0 & 0 & 1 & 1 \\
\hline & & & & & & &
\end{array}\right]
$$

\section{Dominion disintegration:}

Through the reachability medium, reachability established Equality (1) may be alienated in step with specific places of every detail in the structure.

Where, ( i) L R is the reachability established, which worth that the entire detail groups which may be touched as of the detail Ri; $\mathrm{D}(\mathrm{Ri})$ exists, the ahead group, because of this the whole component units which could reach at detail $\mathrm{Ri}$; $\mathrm{T}(\mathrm{Ri})$ exists, not unusual group, that encounters the necessities of formulation (2). At that time, the dominion disintegration may be directed consistently with procedure (2), Refer to Appendix for (Table 4).

\section{Rendering to Table 4}

$T\left(R_{i}\right) \square \square R_{1}, R_{5} \square$

$$
L\left(R_{1}\right) \square L\left(R_{5}\right) \square \square 3,6,7,8 \square
$$

Consequently, $R_{1}$ and $R_{5}$ are in the similar area. Then all the fundamentals can be comprehended in the similar area correspondingly.

\section{Arrangement of Components in the Identical Field:}

As soon as the crossing of reachability group as well as the onward group is equivalent to reachability group, the utmost larger component may be acquired. Like to give or take, the fundamentals that might not influence supplementary components between the structures exist, so termed as the $1^{\text {st }}$ stage components.

$$
\mathrm{Lj}=\left\{\mathrm{Si}(\mathrm{P}-\mathrm{Lo}-\mathrm{L} 1 \ldots . . \mathrm{-Lj}-1) \mid L\left(R_{i}\right) \square D\left(R_{i}\right)=L\left(R_{i}\right)\right\}
$$


Where, $L j$ is the figure of stages, $P$ is the comprehensive set.

\author{
Stage 1: $L_{1} \square \square R 7 \cdot R 8 \square$ \\ Stage 2: $L 2 \square \square R 3 \square$ \\ Stage 3: $L_{3} \square \square R 2, R 4, R_{6}$ \\ Stage 4: $L_{4} \quad \square \quad \square R 1, R 5 \square$
}

As a consequence, the cross stage erection of PGEP plan threats is recognized.

As of Figure 6, each PL threat and $\mathrm{N}$ threat are at rock bottom dwelling, whose incidence would turn out an event and be the probable drive for different threats. It's not tough to grasp that these styles of threats are perpetually outward, and aren't well-ordered by task supervisors. As an example, the govt problems a brand new state strategy, through which it's going to modify the outdoor finance circumstances, substantial costs, equipment employed in the task as well as different situations. By means of these manifestations, E threat, $M$ threat and the $\mathrm{T}$ threat would present itself.

As well, occasionally a province may be overwhelmed by an underground eruption or additional usual tragedies. In this situation, the entire workforce, resources and additional possessions must have to be a place into the renovation and PGEP creation would obviously be dismissed. In contrast, $\mathrm{M}$ risk and $\mathrm{E}$ risk are at the topmost of the arrangement, which worth they are at risk to the influence of supplementary threats. These 2 threats are thoroughly linked to a task the aforementioned, one that is instigated through custom-made conducts of task supervisors and the former normally happens in the multifaceted surroundings of the creation place.

Furthermore, there's associate degree communication amongst $\mathrm{E}$ threat and finance threat that in a straight line domino effect from the usual possessions of the 2 threats. Additionally, consideration should be funded to it $\mathrm{T}$ risk has implicit impact on the $\mathrm{S}$ risk, that is additionally compact in a straight line by monetary and $\mathrm{M}$ threats. because of the inconsistency of stages of budget as well as learning surrounded by regions, the T risk, that leave-takings all over the amount of manufacturing review, strategy, creation, instrumentation producing and construction, could results in clashes in multi-regional and multi-party comes. Consequently, thanks to the probable result between threats, it's wise for task supervisors to reinforce the sooner forecast of threats and address them in while as soon as they happened. For Network task planned threat cross structure grounded on ISM refer to appendix.

\title{
Risk Evaluation
}

\section{Formation of the Evaluation Index System (EIS)}

An EIS is recognized grounded on Analytic Hierarchy Process (AHP), where 5 pointers are using in process to scrutinize the influence of the threats, together with outdated pointers as threat likelihood, threat uncontrollability and period extension lead proportions as well as ground-breaking pointers like threat group as well as threat accountability get-together (Figure 8). In the sequence of starting the IS, the writers well thought-out that influence of threats would somewhat be subject to on the integral characteristics of threats as the consequence of threat examination grounded on ISM, therefore, threat group is added as a significant pointer. 
Furthermore, it's important to require accountability part into consideration, meanwhile, it's understandable that the influence business would tolerate a bigger threat if the obligation gathering were man of affairs, whereas fewer threat in different scenario. Supported AHP, the analysis IS be made up of 3 covers. The highest is that the objective of this threat valuation that is that the threat influence worth. The 2nd cover is that the analysis standard, that take in threat likelihood, threat uncontrollability, length extension lead dimensions, threat class as well as threat accountability gathering. All-time low cover is that the analysis bits and pieces, together with $\mathrm{N}$ risk, E risk, F risk, S risk, M risk, T risk, PL risk and E risk. Also see appendix for Risk EIS diagram Fig 8.

Figure 8: Threat EIS

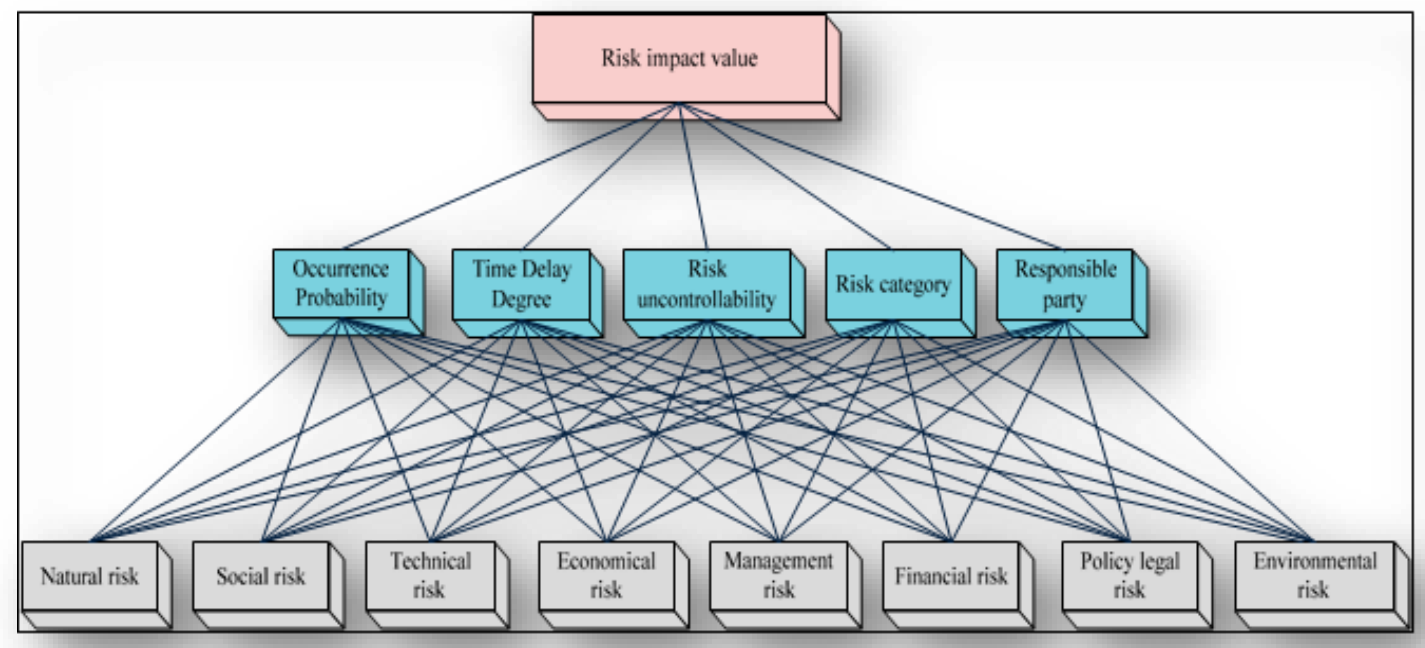

Determination of Threat Effect Significance structure:

The threat influence worth structure is,

Where, $i v$ is the influence worth of threat $i ; j$ exists, the amount of review objective ( $\mathrm{j} \square 1,2,3 \ldots \mathrm{n}$ ) ; $\mathrm{p}$ exists, the threat likelihood significance; $\mathrm{t}$ exists, the distance of the tardy creation era; $u$ exists, the threat uncontrollability worth; r signifies the threat accountability gathering; c signifies the threat group. $\mathrm{p} \mathrm{t} \mathrm{u} \mathrm{c} \mathrm{r} \mathrm{w} \mathrm{,W} \mathrm{,w} \mathrm{,W} \mathrm{,} \mathrm{w} \mathrm{signifies} \mathrm{the} \mathrm{mass} \mathrm{of} \mathrm{threat}$ likelihood, creation period interruption and threat uncontrollability, the threat group and threat accountability gathering in complete influence worth correspondingly.

\section{Determination of Indicator Scoring Criteria:}

Determination of catalogue weightiness:

Grounded on Settee's 1-9 gauge technique, the mass decision surrounding substance is acknowledged, see appendix for (Table 6).

Then, the weightiness of the 5 pointers is achieved.

$$
\left(w_{p}, w_{t}, w_{u}, w_{c}, w_{r}\right) \square(0.225,0.547,0.134,0.047,0.047)
$$


Respectively,

The reliability index C.I $\square 0.08423$;

The regular arbitrary consistency index

R.I $\square 1.12$; the test coefficient $C . R \square$

$0.0752 \square 0.1$, approved.

Consequently, the weightiness of diverse pointers given away in formula (5) are sensibly feasible.

\section{Actual Facts of the Significance of Every Key:}

Over and done by surveys, 91 defendants have spoken their opinions grounded on their proficient facts and effort knowledge. These defendants take account of task supervisors, managers, creators and workforces on location. The statistics in Chart 7 is the regular significance of every pointer's marks. Chart 7 is presented in the appendix.

\section{The Outcomes of the Effect Significance of Every Threat:}

Grounded taking place Calculation (4), the effect significance of the whole threats recognized might be designed. For instance, the conforming responses between the task possibility learning phase are revealed in diagram 9.

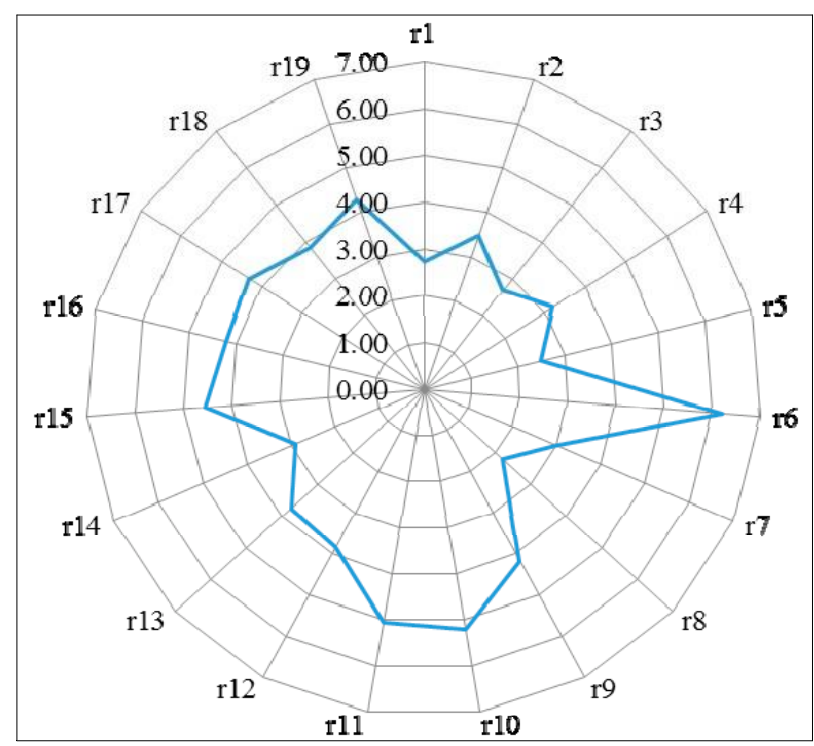

As of the consequences, it indicates that R6 (the shortage or interruption to get hold of significant subdivisions' specialized valuation report, go through explanations and pertinent arrangements) keeps concentrated probable dangers in the probability study period. Keep an eye on by 2 threats, whose mark is stuck between 5 and 6 , they are uncertain groundwork locations and the track statistics, an incorrect task placement as well as control scheduling variations. 
As of the angle of threat possessions, we tend to might categorize and calculate the amount of threats in several cluster (Table 8). Though' the PL threat is that the one with the foremost severe significances and would result in alternative threats' look supported philosophy examination, it's a comparatively low-level threat influence price within the feasibleness study phase. The explanation might consist the little likelihood of incidence of this sort of dangers, like the chance of ups and downs of nationwide strategy, business in operation circumstances and alternative state of affairs. Such threat forever happens subsequent a particular law or is ready to supply a shock absorber amount aimed at supervisors to urge glowing ready.

Furthermore, $M$ threats have a comparatively great threat price during this phase and in the main obvious within the shortage of official papers or inaccuracies in effort process, likewise as unqualified workers. Additionally, $\mathrm{T}$ threats additionally dwell in a major percentage of all the threats during this phase, and its influence price retains at a modest level, that in the main consequences from the method of examination, style add the feasibleness study phase.(see table 8 in appendix).

\section{Risk Prevention (RP):}

Designed for every threat, detailed RP procedures have been guaranteed over and done with discussions with 12 engineers who have eons of knowledge of winning in PGEPs. For instance, the suitable RP procedures in the probability study phase are revealed in Table 9(see appendix).

\section{Conclusions}

In the edict to mark the plan RM of PGEPs further efficient and extra widespread, keep up the supportable administration of PGEPs and endorse the maintainable growth of these 2 grid businesses, this research inaugurates a three-D RM structure, together with supervision workers, supervision phases and supervision approaches. Over and done with surveys and proficient discussions, the research classifies 40 main workings in the PGEPs and 222 threats all over the entire creation procedure. Additional, the threat group and the accountable gathering of every threat are strong-minded. Grounded on ISM model technique, an operational examination of threats is executed.

Consequences display that PL threats and $\mathrm{N}$ threats square measure placed at the lowest of the arrangement, who's taking place can upsurge the possibilities of alternative threats' bang up-to-date. In distinction, $M$ threats and $\mathrm{E}$ threats are placed on the highest, that square measure the foremost susceptible and simply tormented by alternative threats. S threats square measure placed on the 3rd level, which might be elicited by the $\mathrm{E}, \mathrm{F}$ and $\mathrm{T}$ threats, associate degree funding and $\mathrm{E}$ threats have collaboration on one another. Within the threat valuation part, supported the AHP philosophy, a 3-tier analysis structure is recognized, wherever catalogues comprise threat chance, threat uncontrollability, period extension lead dimensions, threat class and threat accountability gathering.

Constructed on the review consequences, threats of a insufficiency or a interruption in getting important subdivisions' skilled valuation report and pertinent arrangements square measure the best threats throughout the feasibleness study amount in a very PGEP, shadowed by the threats of uncertain structure data still as control coming up with variations. In the meantime, $\mathrm{M}$ and $\mathrm{T}$ threats have accounted for the most important percentage at this phase and 
their worth of influence is comparatively extraordinary. In distinction, the effect worth of PL threats that discover within the straightforward place within the theoretical structure examination is short at this phase, thanks to the minor likelihood of their prevalence. Lastly, pre-control processes square measure urged and developed for all the threats.

Grounded on the planned structure of plan RM for PGEPs, executives will simply realize the sternness of every threat, bear in mind of their odd jobs, proceeds activities prior to and cling to change the tilt. The plan RM at intervals the corporate and all over the whole creation method will advance the potency of RM of PGEPs and enhance their property, and this context might get some stimulus and situation worth for the contributors of PGEPs.

\section{Appendix:}

Figure 6: The number of R' of every main work knot in every phase

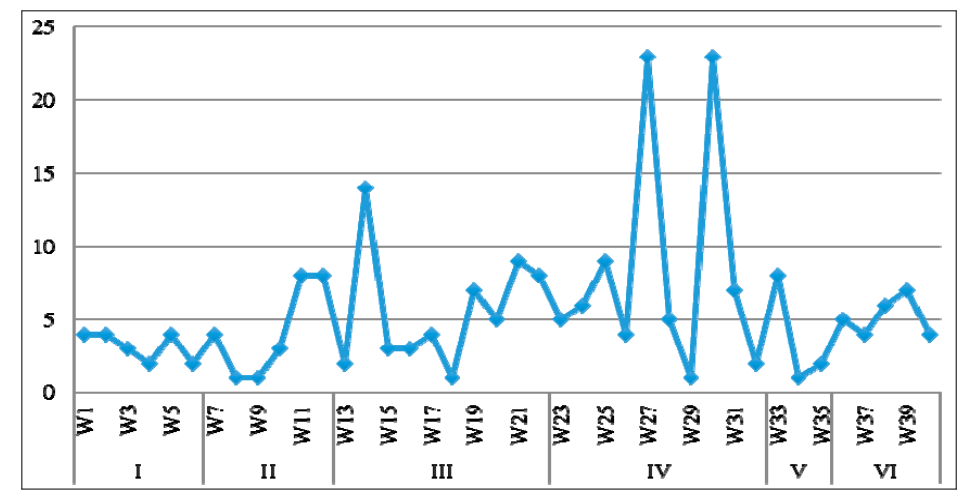

Table 2: RI and R' bases in Probability Study Phase

\begin{tabular}{|c|c|c|c|c|}
\hline $\begin{array}{l}\text { Key } \\
\text { Work }\end{array}$ & Risk & $\begin{array}{l}\text { S.N } \\
0\end{array}$ & $\begin{array}{l}\text { Risk } \\
\text { Ctgry }\end{array}$ & $\begin{array}{l}\text { Responsible } \\
\text { Party }\end{array}$ \\
\hline$W 1$ & $\begin{array}{l}\text { Infeasible financial and practical pointers } \\
\text { Indeterminate tendencies of impartial possessions and } \\
\text { prediction nonconformity Errors occurred in } \\
\text { groundwork of task suggestions } \\
\text { Assignment content is unpredictable with the real }\end{array}$ & $\begin{array}{l}r 1 \\
r 2 \\
r 3 \\
r 4\end{array}$ & $\begin{array}{l}\text { TR } \\
\text { TR } \\
\text { TR } \\
\text { TR }\end{array}$ & $\begin{array}{l}\mathrm{P} \text { (proprietor) } \\
\mathrm{P} \\
\mathrm{P} \\
\mathrm{P}\end{array}$ \\
\hline$W 2$ & $\begin{array}{l}\text { Initial physical examination is congested } \\
\text { Lost or deferral in procurement of pertinent sections' } \\
\text { expert } \\
\text { valuation report, studying explanations and relevant } \\
\text { contracts }\end{array}$ & $\begin{array}{l}r 5 \\
r 6\end{array}$ & $\begin{array}{l}\text { SR } \\
\text { MR }\end{array}$ & $\begin{array}{l}\mathrm{P} \\
\mathrm{P}\end{array}$ \\
\hline & $\begin{array}{l}\text { Variations of state strategy, business working } \\
\text { situations and other situations }\end{array}$ & $r 7$ & PLR & $\mathrm{P}$ \\
\hline
\end{tabular}




\begin{tabular}{|c|c|c|c|c|}
\hline & $\begin{array}{l}\text { Improper or flawed task suggestion, clashes against the } \\
\text { administration's planned }\end{array}$ & $r 8$ & TR & $\mathrm{P}$ \\
\hline \multirow[t]{3}{*}{ W3 } & $\begin{array}{l}\text { Review data and info is not comprehensive, incorrect } \\
\text { or improper }\end{array}$ & r9 & TR & $\mathrm{P}$ \\
\hline & $\begin{array}{l}\text { Substructure sites and the path information is not } \\
\text { detailed, project site and planning, engineering } \\
\text { geology is wrong }\end{array}$ & $r 10$ & TR & $\mathrm{P}$ \\
\hline & Control preparation variations & $r 11$ & ER & $\mathrm{P}$ \\
\hline \multirow[t]{2}{*}{$W 4$} & Task assessment and review is improper & $r 12$ & MR & $\mathrm{P}$ \\
\hline & Specialists or advisers are measured definite & $r 13$ & MR & $\mathrm{P}$ \\
\hline \multirow[t]{4}{*}{ W5 } & $\begin{array}{l}\text { Task endorsement request report equipped is flawed, } \\
\text { and not timely } \\
\text { succumbed to the National Development and Reform } \\
\text { Commission(NTDC) }\end{array}$ & $r 14$ & TR & $\mathrm{P}$ \\
\hline & $\begin{array}{l}\text { Preparation advice, terrestrial pretrial view and other } \\
\text { accepted data are imperfect }\end{array}$ & $r 15$ & TR & $\mathrm{P}$ \\
\hline & Tasks are not accepted or postponement & $r 16$ & MR & $\mathrm{P}$ \\
\hline & $\begin{array}{l}\text { Remarks of local viability evaluation are lost or } \\
\text { overdue }\end{array}$ & $r 17$ & MR & $\mathrm{P}$ \\
\hline \multirow[t]{2}{*}{ W6 } & $\begin{array}{l}\text { Nonconformity of possibility size and gauge accepted } \\
\text { is too large }\end{array}$ & $r 18$ & TR & $\mathrm{P}$ \\
\hline & $\begin{array}{l}\text { Documents of accepted probability study of company } \\
\text { and other forms are not delivered or postponement }\end{array}$ & $r 19$ & MR & $\mathrm{P}$ \\
\hline
\end{tabular}

TABLE 3: GRID TASK PLAN R' CONNECTION MATRIX

\begin{tabular}{|c|c|c|c|c|c|c|c|c|}
\hline $\boldsymbol{R}_{i}^{\boldsymbol{R}_{j}}$ & $\begin{array}{l}R \\
1\end{array}$ & $\begin{array}{l}\boldsymbol{R} \\
2\end{array}$ & $\begin{array}{l}\boldsymbol{R} \\
3\end{array}$ & $\begin{array}{l}\boldsymbol{R} \\
4\end{array}$ & $\begin{array}{l}\boldsymbol{R} \\
5\end{array}$ & $\begin{array}{l}R \\
6\end{array}$ & $\begin{array}{l}\boldsymbol{R} \\
7\end{array}$ & $\begin{array}{l}R \\
8\end{array}$ \\
\hline $\boldsymbol{R}$ & 1 & 0 & 0 & 0 & 0 & 0 & 1 & 1 \\
\hline $\boldsymbol{R}$ & 0 & 1 & 1 & 1 & 0 & 0 & 1 & 1 \\
\hline $\begin{array}{l}2 \\
R\end{array}$ & 0 & 0 & 1 & 0 & 0 & 0 & 0 & 1 \\
\hline $\begin{array}{l}3 \\
\boldsymbol{R} \\
4\end{array}$ & 0 & 1 & 1 & 1 & 0 & 0 & 1 & 1 \\
\hline $\begin{array}{l}\boldsymbol{R} \\
5\end{array}$ & 0 & 1 & 1 & 1 & 1 & 0 & 1 & 1 \\
\hline $\begin{array}{l}R \\
6\end{array}$ & 0 & 0 & 1 & 0 & 0 & 1 & 1 & 1 \\
\hline
\end{tabular}




\begin{tabular}{|l|l|l|l|l|l|l|l|l|}
\hline $\begin{array}{l}R \\
7\end{array}$ & 0 & 0 & 0 & 0 & 0 & 0 & 1 & 1 \\
\hline$R$ & 0 & 0 & 0 & 0 & 0 & 0 & 0 & 1 \\
\hline
\end{tabular}

Table 4: Outcomes of domain decomposition

\begin{tabular}{llll}
\hline$\underline{\underline{i}}$ & $\underline{\boldsymbol{L}\left(\boldsymbol{R}_{i}\right)}$ & $\underline{\boldsymbol{D}\left(\boldsymbol{R}_{\boldsymbol{i}}\right)}$ & $\underline{\boldsymbol{L}\left(\boldsymbol{R}_{\boldsymbol{i}}\right)} \underline{\square \boldsymbol{D}\left(\boldsymbol{R}_{\underline{i}}\right)}$ \\
\hline 1 & $1,3,6,7,8$ & $\mathbf{1}$ & $\mathbf{1}$ \\
2 & $2,3,4,7,8$ & $2,4,5$ & 2,4 \\
3 & $3,7,8$ & $1,2,3,4,5,6$ & 3 \\
4 & $2,3,4,7,8$ & $2,4,5$ & 2,4 \\
5 & $2,3,4,5,6,7,8$ & $\mathbf{5}$ & $\mathbf{5}$ \\
6 & $3,6,7,8$ & $1,5,6$ & $\mathbf{6}$ \\
7 & 7,8 & $1,2,3,4,5,6,7,8$ & 7,8 \\
8 & 7,8 & $1,2,3,4,5,6,7,8$ & 7,8 \\
\hline
\end{tabular}

Figure 8: RE index structure

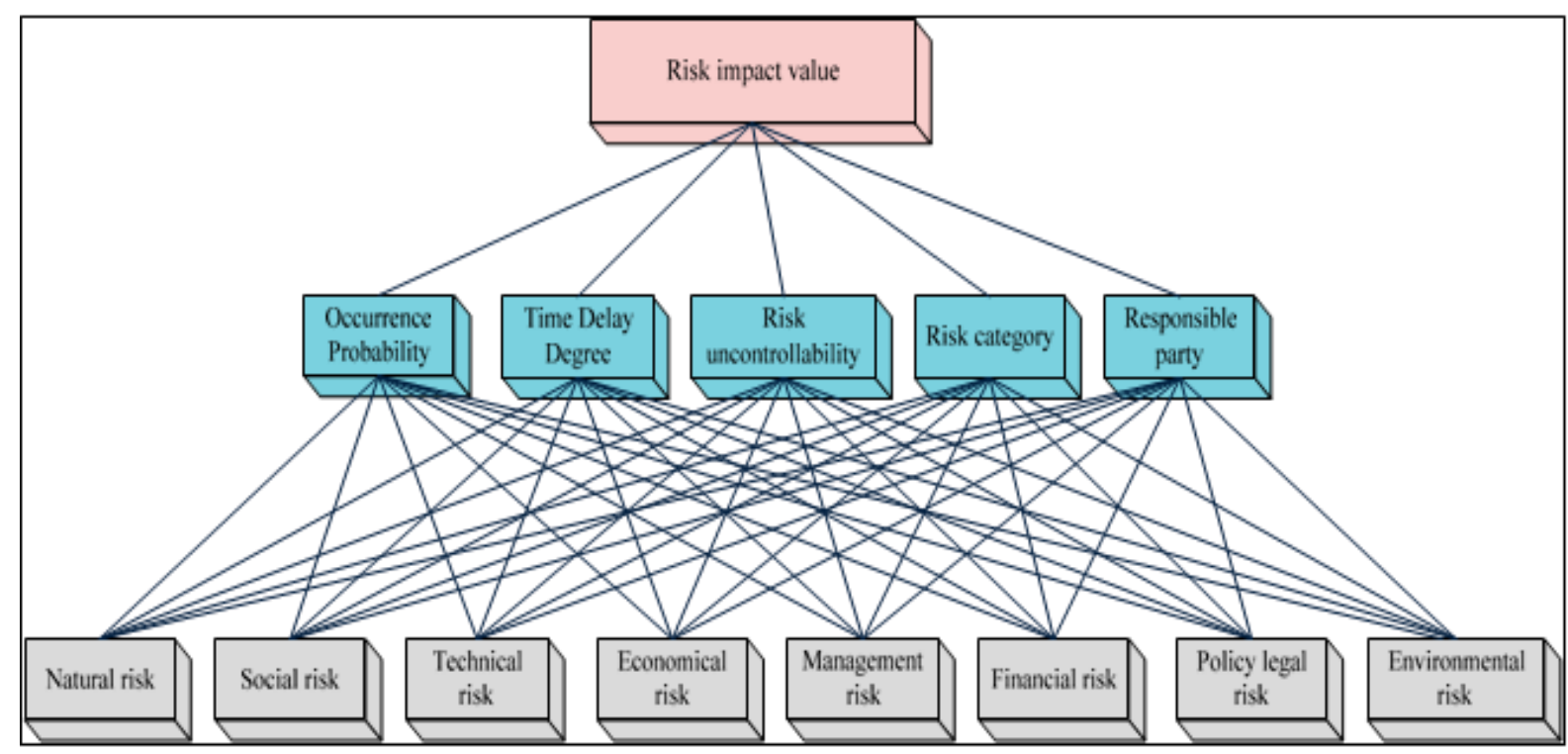

The rating criteria of the 5 indicators are shown in Table 5.

Table 5: Risk evaluation rating rules. (a) Rating rules for occurrence probability, time delay degree and risk uncontrollability; (b) Rating rules for risk category and risk responsibility party. 
Table 6: Weight decision matrix

\begin{tabular}{lllllll}
\hline & $\mathbf{P}$ & $\mathrm{T}$ & $\mathrm{U}$ & $\mathrm{C}$ & $\mathbf{R}$ \\
\hline $\boldsymbol{p}$ & 1 & 0.33 & 3 & 4 & $\mathbf{4}$ \\
$\boldsymbol{t}$ & 3 & 1 & 7 & 8 & $\mathbf{8}$ \\
$\boldsymbol{u}$ & 0.33 & 0.14 & 0.2 & 5 & $\mathbf{5}$ \\
$\boldsymbol{c}$ & 0.25 & 0.125 & $\mathbf{0 . 2}$ & 1 & $\mathbf{1}$ \\
\hline $\boldsymbol{r}$ & $\mathbf{0 . 2 5}$ & $\mathbf{0 . 1 2 5}$ & $\mathbf{1}$ & $\mathbf{1}$ \\
\hline
\end{tabular}

Table7: Scoring value of risks in feasibility study stage

\begin{tabular}{l|llll|l}
$\begin{array}{l}\text { Serial } \\
\text { Number }\end{array}$ & $\begin{array}{l}\text { Occurrence } \\
\text { Probability }\end{array}$ & $\begin{array}{l}\text { Time Delay } \\
\text { Degree }\end{array}$ & $\begin{array}{l}\text { Risk } \\
\text { Uncontrollabil } \\
\text { ity }\end{array}$ & $\begin{array}{l}\text { Risk } \\
\text { Categorie } \\
\text { s }\end{array}$ & $\begin{array}{l}\text { Responsible } \\
\text { Party }\end{array}$ \\
\hline$r_{1}$ & 1.24 & 3.75 & 1.03 & 3 & 3 \\
$r_{2}$ & 2.25 & 3.99 & 3.75 & 3 & 3 \\
$r_{3}$ & 1.24 & 3.49 & 1.52 & 3 & 3 \\
$r_{4}$ & 2.48 & 3.75 & 2.51 & 3 & 3 \\
$r_{5}$ & 2.99 & 2.25 & 2.75 & 2 & 3 \\
$r_{6}$ & 4.35 & 7.25 & 8.24 & 1 & 3 \\
$r_{7}$ & 1.48 & 3.50 & 3.11 & 4 & 3 \\
$r_{8}$ & 0.90 & 2.75 & 1.75 & 3 & 3 \\
$r_{9}$ & 4.52 & 4.49 & 3.25 & 3 & 3 \\
$r_{10}$ & 4.79 & 5.75 & 5.12 & 3 & 3 \\
$r_{11}$ & 3.47 & 6.25 & 4.24 & 3 & 3 \\
$r_{12}$ & 3.39 & 4.49 & 3.24 & 1 & 3 \\
$r_{13}$ & 4.02 & 3.99 & 3.52 & 1 & 3 \\
$r_{14}$ & 1.25 & 3.90 & 1.57 & 3 & 3 \\
$r_{15}$ & 2.99 & 5.50 & 4.51 & 3 & 3 \\
$r_{16}$ & 1.50 & 5.97 & 3.25 & 1 & 3 \\
$r_{17}$ & 2.01 & 5.69 & 4.23 & 1 & 3 \\
$r_{18}$ & 1.75 & 4.88 & 3.75 & 3 & 3 \\
$r_{19}$ & 1.25 & 6.46 & 2.12 & 1 & 3 \\
\cline { 2 - 6 } & & & & &
\end{tabular}

Outcomes of the Influence Value of Every R': 


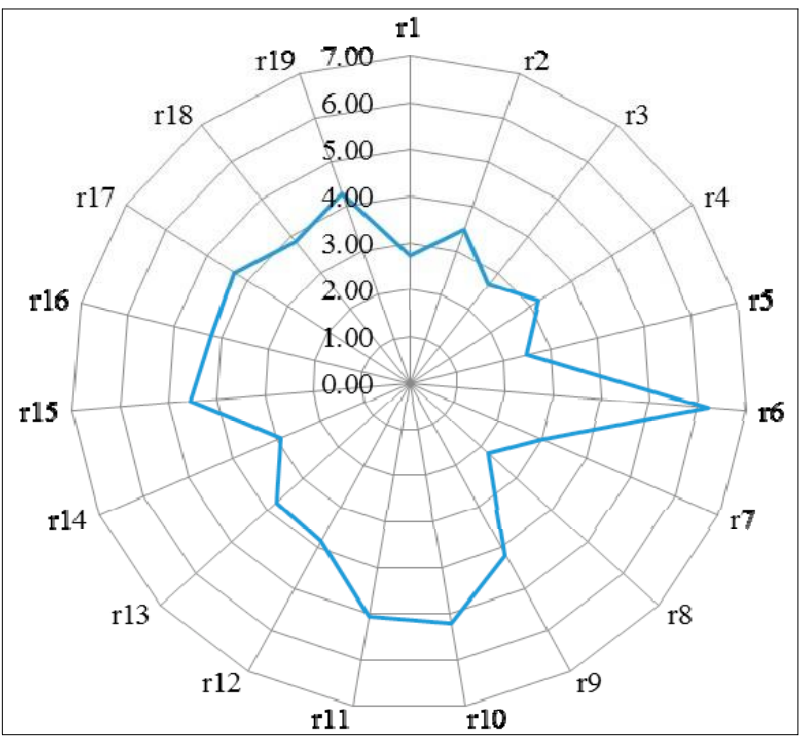

Table 8: The number of $R^{\prime}$ with diverse possessions in dissimilar value group

\begin{tabular}{|c|c|c|c|c|c|c|}
\hline Property & TR & SR & MR & PLR & ER & Total \\
\hline$(2,3)$ & 4 & 1 & 0 & 1 & 0 & 6 \\
\hline$(3,4)$ & 3 & 0 & 2 & 0 & 0 & 5 \\
\hline$(4,5)$ & 2 & 0 & 3 & 0 & 0 & 5 \\
\hline$(5,6)$ & 1 & 0 & 0 & 0 & 1 & 2 \\
\hline$(6,7)$ & 0 & 0 & 1 & $\mathbf{0}$ & 0 & 1 \\
\hline
\end{tabular}

Table 9: $R$ ' prevention actions in the probability study phase

\begin{tabular}{|c|c|c|}
\hline $\begin{array}{l}\text { K.W } \\
\text { Nod } \\
\text { e }\end{array}$ & $\begin{array}{l}\text { Risk } \\
\text { Node }\end{array}$ & Prevention Measures \\
\hline \multirow[t]{4}{*}{$\overline{W_{1}}$} & $r_{1}$ & Choosing technical and sensible financial and practical pointers \\
\hline & $r_{2}$ & $\begin{array}{l}\text { Consuming technical approaches to progress the correctness of the } \\
\text { predictions }\end{array}$ \\
\hline & r3 & $\begin{array}{l}\text { Gathering data of comparable tasks, likening and examining the real situation } \\
\text { of the planned task, and sensible policymaking }\end{array}$ \\
\hline & r4 & Succeeding the initial review \\
\hline \multirow[t]{4}{*}{$W 2$} & r5 & An suitable upsurge of reimbursement values \\
\hline & r6 & $\begin{array}{l}\text { Organization of the pertinent sections under the local secondary business; } \\
\text { Preparation and enterprise units ornamental communiqué with other } \\
\text { businesses }\end{array}$ \\
\hline & $r 7$ & Regulating the variety of wealth using strategy \\
\hline & $r 8$ & Refining the level of package project \\
\hline
\end{tabular}




\begin{tabular}{|c|c|c|}
\hline \multirow[t]{3}{*}{ W3 } & r9 & $\begin{array}{l}\text { Succeeding initial examination, firming physical searching confirming the } \\
\text { info precise and applied }\end{array}$ \\
\hline & $r 10$ & Ornamental the valuation to the review and enterprise objects \\
\hline & $r 11$ & Framing a balanced strategy of endowments' by \\
\hline \multirow[t]{2}{*}{ W4 } & $r 12$ & Refining the valuation correctness and counting the ruling \\
\hline & $r 13$ & Ornamental the valuation to referring object \\
\hline \multirow[t]{4}{*}{ W5 } & $r 14$ & Enlightening the competence of effort \\
\hline & $r 15$ & $\begin{array}{l}\text { Reinforce the message with pertinent sections, timely make the whole } \\
\text { physical }\end{array}$ \\
\hline & $r 16$ & Establishment the message with pertinent sections \\
\hline & $r 17$ & Consolidation the message with the local lesser business \\
\hline \multirow[t]{2}{*}{ W6 } & $r 18$ & $\begin{array}{l}\text { Dropping personal issues and refining the complexity and correctness } \\
\text { probability study }\end{array}$ \\
\hline & $r 19$ & Establishment the message with the NTDC \\
\hline
\end{tabular}

\section{TABLE}

\begin{tabular}{|c|c|c|}
\hline Node & S.No & Risk Node \\
\hline \multirow[t]{4}{*}{ W1 } & R1 & Infeasible financial and practical pointers \\
\hline & $\mathrm{R} 2$ & Undefined tendencies of objective possessions \& prognosis nonconformity \\
\hline & R3 & Errors occurred in grounding of task applications \\
\hline & R4 & Task gratified is unpredictable by the real \\
\hline \multirow[t]{4}{*}{ W2 } & R5 & Initial physical examination is congested \\
\hline & R6 & $\begin{array}{l}\text { Pertinent sections' specialized valuation report, revising explanations and } \\
\text { pertinent arrangements are misplaced or deferral in procurement }\end{array}$ \\
\hline & R7 & National policy, company operating conditions and other conditions change. \\
\hline & $\mathrm{R} 8$ & $\begin{array}{l}\text { Task suggestion is improper or flawed, a conflict occurred in contradiction } \\
\text { of the government's calculated }\end{array}$ \\
\hline \multirow[t]{3}{*}{ W3 } & R9 & Review data and info is not comprehensive, false or improper \\
\hline & $\mathrm{R} 10$ & $\begin{array}{l}\text { Infrastructure sites and the path information is not detailed, project siting and } \\
\text { preparation, engineering geology is wrong. }\end{array}$ \\
\hline & R11 & Control preparation ups and downs \\
\hline \multirow[t]{2}{*}{ W4 } & $\mathrm{R} 12$ & Task assessment and inspection is improper \\
\hline & R13 & Specialists or advisers are evaluated outright \\
\hline \multirow[t]{4}{*}{ W5 } & $\mathrm{R} 14$ & $\begin{array}{l}\text { Task endorsement request report equipped is flawed, and not well-timed } \\
\text { acquiesced to the NTDC }\end{array}$ \\
\hline & $\mathrm{R} 15$ & $\begin{array}{l}\text { Preparation information, land pretrial view, the EIA and other accepted data } \\
\text { are imperfect }\end{array}$ \\
\hline & R16 & Tasks are not accepted over and done with the endorsement or postponement \\
\hline & $\mathrm{R} 17$ & Explanations of Local possibility evaluation are misplaced or delayed \\
\hline \multirow[t]{2}{*}{ W6 } & $\mathrm{R} 18$ & Nonconformity of probability size and scale accepted is too large \\
\hline & $\mathrm{R} 19$ & $\begin{array}{l}\text { Accepted probability study of company and other papers are not delivered or } \\
\text { deferral }\end{array}$ \\
\hline W7 & $\mathrm{R} 20$ & Accepted document of NTDC is not accepted and probability review \\
\hline
\end{tabular}




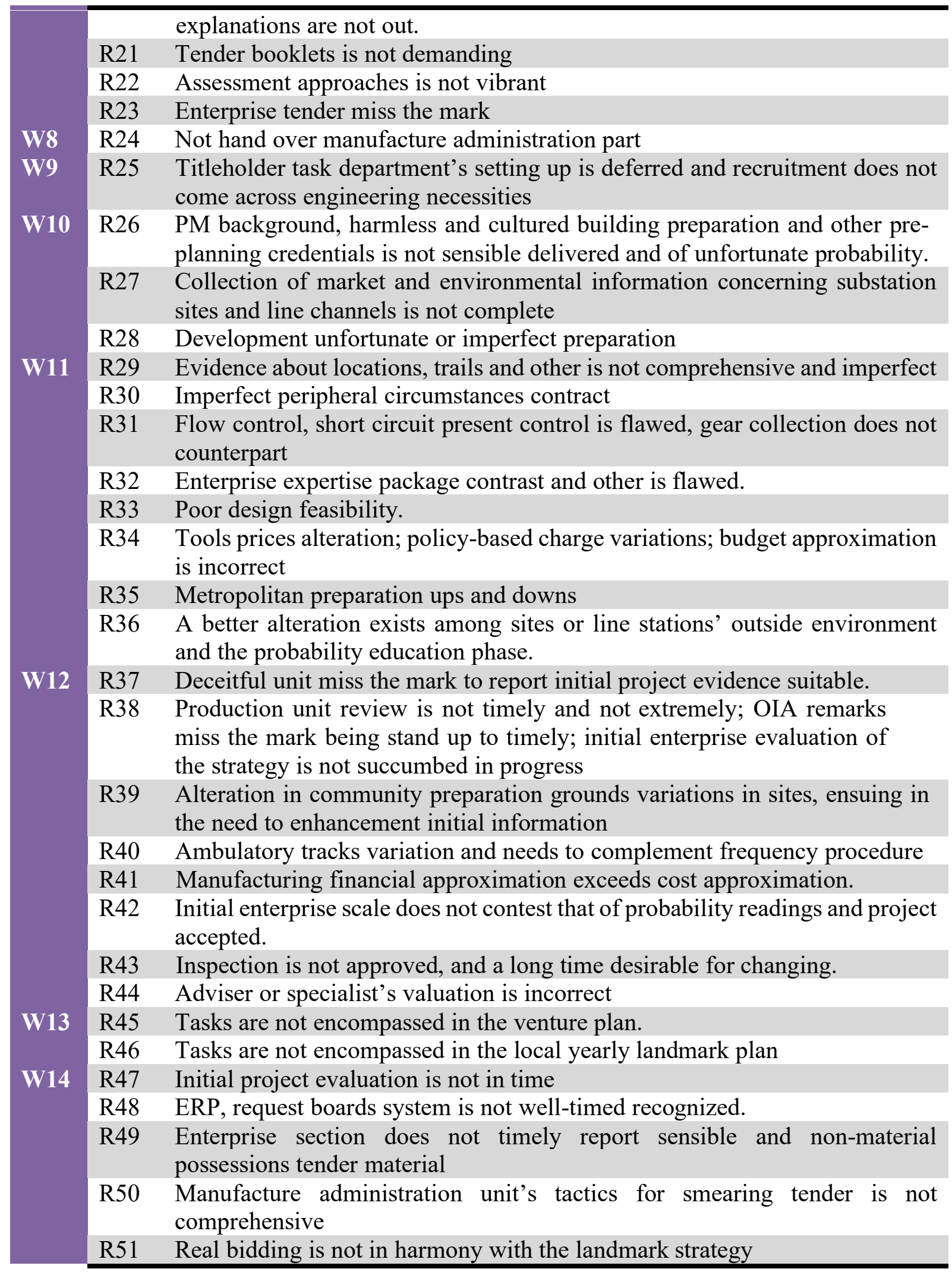




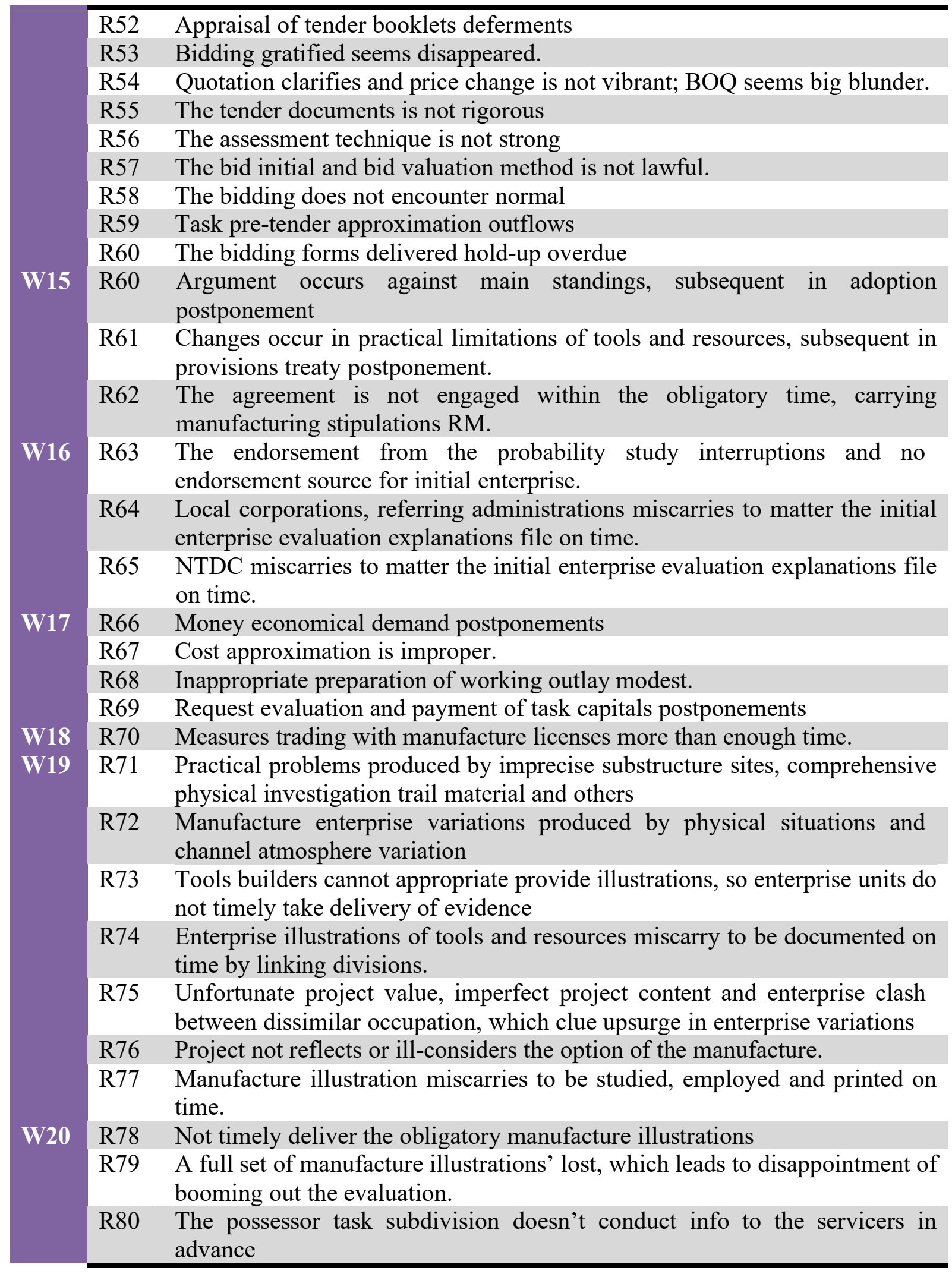




\begin{tabular}{|c|c|c|}
\hline & 81 & $\begin{array}{l}\text { Project and structure illustrations are tested as a simple decorum, cannot } \\
\text { efficiently find project mistakes or oversights }\end{array}$ \\
\hline & R82 & $\begin{array}{l}\text { Manufacture illustrations' evaluation and enterprise assignment } \\
\text { adjournments. }\end{array}$ \\
\hline \multirow[t]{9}{*}{ W21 } & R83 & Low competence of the pertinent administration sections \\
\hline & R84 & Response of land expropriation compassionate evidence deferrals or deceases \\
\hline & R85 & $\begin{array}{l}\text { Preparation of city, county (district), and settlement's scheduling sections is } \\
\text { not totally reliable, subsequent in deferral in border review and scheduling } \\
\text { approval. }\end{array}$ \\
\hline & R86 & The environment of the substation land ups and downs. \\
\hline & R87 & Location site atmosphere, landscape and biological situations variation \\
\hline & R88 & $\begin{array}{l}\text { Manufacture site covers inorganic capitals and social residues, which leads to } \\
\text { the alteration in site }\end{array}$ \\
\hline & R89 & $\begin{array}{l}\text { Terrestrial procurement costs cannot be opportune payment and } \\
\text { reimbursement does not influence the chosen location }\end{array}$ \\
\hline & R90 & $\begin{array}{l}\text { Native inhabitants congested and other outside ecological features lead to land } \\
\text { expropriation problems. }\end{array}$ \\
\hline & R91 & Land use procedures postponement \\
\hline \multirow[t]{8}{*}{ W22 } & R92 & ial effects \\
\hline & R93 & Path \\
\hline & R94 & $\begin{array}{l}\text { alternative task of large operators } \\
\text { characteristic period }\end{array}$ \\
\hline & R95 & The reimbursement does not influence the chosen location. \\
\hline & R96 & $\begin{array}{l}\text { Control, water resource and others do not pass, subsequent in manufacture } \\
\text { problems }\end{array}$ \\
\hline & R97 & Sluggish employment of public infrastructures block station road \\
\hline & R98 & erdue \\
\hline & R99 & isional abilities' manufacture hold-ups \\
\hline \multirow[t]{5}{*}{ W23 } & R100 & Servicers and manufacture management is not equipped to timely method \\
\hline & R101 & Not appropriate source satisfactory constituents \\
\hline & R102 & $\begin{array}{l}\text { Working circumstances are not competent, so the task executive cannot } \\
\text { accept inauguration report }\end{array}$ \\
\hline & R103 & aterial about the manufacture license cannot be accepted. \\
\hline & R104 & ction. \\
\hline \multirow[t]{6}{*}{ W24 } & R105 & $\begin{array}{l}\text { Manufacture association enterprise, manufacture arrangement's examination } \\
\text { is improper }\end{array}$ \\
\hline & R106 & Manufacture development strategy is short of appropriateness or operability \\
\hline & R107 & id attainment processes are not comprehensive \\
\hline & R108 & $\begin{array}{l}\text { Manufacture workforces' experiences, knowledge, level and number cannot } \\
\text { encounter the manufacture requirements. }\end{array}$ \\
\hline & R109 & $\begin{array}{l}\text { Connected measures and employment of provisional control supply and water } \\
\text { supply tasks are not appropriate }\end{array}$ \\
\hline & R110 & Mechanism on the table for inspection is not concluded. \\
\hline W25 & R111 & Arguments instigated by deprived statement \\
\hline
\end{tabular}




\begin{tabular}{|c|c|c|}
\hline & R112 & Ambiguities in security administration \\
\hline & R113 & $\begin{array}{l}\text { Manufacture workforces do not comprehend the security and sanctuary of } \\
\text { working information }\end{array}$ \\
\hline & R114 & No practical dealings for protection and excellence \\
\hline & R115 & Protection and excellence practical amount is not impeccable \\
\hline & R116 & Corrective and destruction jobs take place \\
\hline & R117 & Worker does not encounter the necessities. \\
\hline & $\mathrm{R} 118$ & $\begin{array}{l}\text { Great } \mathrm{R} \text { task is not prepared with harmless manufacture effort coupon, and } \\
\text { on-site management does not influence the chosen location }\end{array}$ \\
\hline & R119 & $\begin{array}{l}\text { Distinct manufacture work does not have different protection and } \\
\text { excellence strategy; distinct strategy evaluation postponements or is not } \\
\text { severe }\end{array}$ \\
\hline W26 & $\mathrm{R} 120$ & $\begin{array}{l}\text { Consultation not being equipped sufficiently most important to incompetent } \\
\text { evidence communication }\end{array}$ \\
\hline & R121 & $\begin{array}{l}\text { The mistakes and oversights in discussion, lead to be unsuccessful } \\
\text { reproducing and resolving glitches in a timely method. }\end{array}$ \\
\hline & R122 & $\begin{array}{l}\text { The possessor, management and manufacture task subdivision workers } \\
\text { cannot influence the chosen location }\end{array}$ \\
\hline & R123 & Task conferences develop a simple convention. \\
\hline W27 & R124 & $\begin{array}{l}\text { Manufacture task division administration cannot encounter the requirements } \\
\text { of the manufacture, manufacture association and plan is irrational, which } \\
\text { seems illogicalities amongst each type of effort and procedure, then upsetting } \\
\text { the timetable. }\end{array}$ \\
\hline & $\mathrm{R} 125$ & $\begin{array}{l}\text { Project ground workers cannot timely, rendering to the obligation, solve } \\
\text { enterprise glitches in manufacture course }\end{array}$ \\
\hline & $\mathrm{R} 126$ & Reimbursement normal along the network is not reliable \\
\hline & R127 & Seeming stoppage spectacle, outcomes in manufacture disagreements \\
\hline & R128 & $\begin{array}{l}\text { The possessor task division executives cannot grip manufacturing difficulties } \\
\text { in a timely method }\end{array}$ \\
\hline & R129 & $\begin{array}{l}\text { Reality of numerous protection and excellence Rs, provided that Rs to the } \\
\text { development of the development }\end{array}$ \\
\hline & $\mathrm{R} 130$ & PM Division cannot timely recompense for effort rendering to the agreement \\
\hline & R131 & $\begin{array}{l}\text { Water supply, power supply amenities and manufacture equipment tools for } \\
\text { manufacture continuously miscarries. }\end{array}$ \\
\hline & R132 & $\begin{array}{l}\text { Undergoing unnecessary groundwater, morass, physical responsibilities, } \\
\text { fissures; determining suppressed subversive ethnic residues; determining } \\
\text { fragments of war ammo in the manufacture }\end{array}$ \\
\hline & R133 & $\begin{array}{l}\text { Upheavals, overflows and other power majeure Rs to the development of the } \\
\text { task }\end{array}$ \\
\hline & R134 & $\begin{array}{l}\text { Foremost governmental proceedings, societal undertakings, and variations in } \\
\text { the financial state }\end{array}$ \\
\hline & R135 & Line networks' variations instigated by outside ecological issues. \\
\hline & R136 & Foremost variations in manufacturing enterprise \\
\hline
\end{tabular}




\begin{tabular}{|c|c|c|}
\hline & 137 & $\begin{array}{l}\text { Manufacture workforces decrease throughout the demanding periods or } \\
\text { nationwide outings }\end{array}$ \\
\hline & 138 & Raining, season, high temperatures and additional climate influences. \\
\hline & 139 & Manufacture elements have inadequate reserves, or organize irrational \\
\hline & R140 & Fewer work servicer or insufficient supply of manufacture equipment. \\
\hline & R141 & $\begin{array}{l}\text { Manufacture substances' high market price, long attaining series and inferior } \\
\text { class }\end{array}$ \\
\hline & R142 & $\begin{array}{l}\text { Tools and matters' catalogue is incorrect, lead to oversights or inadequate } \\
\text { number of gaining. }\end{array}$ \\
\hline & R143 & $\begin{array}{l}\text { The level of manufacture workforces cannot encounter the manufacture } \\
\text { requirements, which leads to modify }\end{array}$ \\
\hline & R144 & Normal manufacture course be unsuccessful, subsequent in modify \\
\hline & R145 & $\begin{array}{l}\text { Revise due to the mistake of manufacture illustration and other enterprise } \\
\text { explanations }\end{array}$ \\
\hline & R146 & $\begin{array}{l}\text { Managers' specialized class is inferior, or amount is minor, who miss the } \\
\text { mark to yield operative processes to assurance the manufacturing production. }\end{array}$ \\
\hline W & R147 & $\begin{array}{l}\text { Civil engineering's excellence does not encounter the necessities. } \\
\text { Taking file is not comprehensive }\end{array}$ \\
\hline & & ted on period \\
\hline & & Mass groundwork of line is mi \\
\hline & & ffort postponements \\
\hline & R148 & The presence of class imperfections \\
\hline & R149 & $\begin{array}{l}\text { Tools has eminence difficulties or does not imitate to the necessities of } \\
\text { pertinent principles }\end{array}$ \\
\hline & R150 & The illustrations delivered by the tools contractors do not count with the tools \\
\hline & R151 & Tools physical record is incorrect \\
\hline & R152 & $\begin{array}{l}\text { Proprietors task division administrators cannot grip manufacturing } \\
\text { difficulties, subsequent in the clash among manufacture components and } \\
\text { contractors of resources and tools }\end{array}$ \\
\hline & R153 & $\begin{array}{l}\text { Project ground workers cannot timely, resolve project difficulties in } \\
\text { manufacture method }\end{array}$ \\
\hline & R154 & $\begin{array}{l}\text { Managers' specialized excellence is deprived, or amount is minor, and } \\
\text { miscarries to assurance the manufacturing manufacture }\end{array}$ \\
\hline & R155 & $\begin{array}{l}\text { The excellence of manufacture workforces cannot encounter the manufacture } \\
\text { desires, which hints to revise }\end{array}$ \\
\hline & R156 & $\begin{array}{l}\text { Tools and matter's obtaining series is extended, and the supply is not } \\
\text { appropriate; resources excellence cannot encounter the } \\
\text { manufacture requests }\end{array}$ \\
\hline & R157 & Fewer work servicer or insufficient supply of manufacture equipment \\
\hline & R158 & spectacle, which consequences in manufacture arguments \\
\hline & R159 & $\begin{array}{l}\text { Presence of numerous protection and excellence Rs, provided that Rs to the } \\
\text { development of the task. }\end{array}$ \\
\hline & R160 & Line networks' variations instigated by outside ecological influences \\
\hline & R161 & Foremost variations in manufacturing project \\
\hline
\end{tabular}




\begin{tabular}{|c|c|c|}
\hline & R162 & $\begin{array}{l}\text { Manufacture employees decrease due to the busy periods or nationwide } \\
\text { breaks }\end{array}$ \\
\hline & R163 & Rainy, winter, high temperatures and other weather factors \\
\hline & R164 & Manufacture components have inadequate reserves, or irrational plan \\
\hline & R165 & $\begin{array}{l}\text { Tools and substances' inventory is incorrect, which clues to oversights or } \\
\text { inadequate amount of tracking down }\end{array}$ \\
\hline & R166 & PM Division cannot appropriate pay for effort rendering to the agreement \\
\hline & R167 & $\begin{array}{l}\text { Water supply, power supply services and manufacture equipment tools for } \\
\text { manufacture always be unsuccessful }\end{array}$ \\
\hline & R168 & Main resources, tools, technologies and outfits are robbery or spoiled \\
\hline & R169 & Revise due to inferior manufacture method \\
\hline & $\mathrm{R} 170$ & $\begin{array}{l}\text { Revise due to the mistake of manufacture illustration and other enterprise } \\
\text { details }\end{array}$ \\
\hline & R171 & $\begin{array}{l}\text { The administration of manufacture task section cannot encounter the } \\
\text { requirements of the manufacture, which looks inconsistencies among each } \\
\text { type of effort and method. }\end{array}$ \\
\hline W31 & $\mathrm{R} 172$ & $\begin{array}{l}\text { Power grid shutdown. throughout the era of state (or local) significant } \\
\text { centenary or actions, and unusual summer points }\end{array}$ \\
\hline & R173 & $\begin{array}{l}\text { Line networks' variations and clearance problems produced by outside } \\
\text { ecological influences }\end{array}$ \\
\hline & R174 & Tools industrialist is not in place, so practical provision is not sufficient. \\
\hline & $\mathrm{R} 175$ & $\begin{array}{l}\text { Project field workers cannot timely, resolve enterprise difficulties in } \\
\text { manufacture method }\end{array}$ \\
\hline & $\mathrm{R} 176$ & $\begin{array}{l}\text { The complete task is not accomplished, which hints to usual joint contracting } \\
\text { disappointment. }\end{array}$ \\
\hline & R177 & $\begin{array}{l}\text { Tools indemnities or supplies are not constant, etc., distressing the usual } \\
\text { correcting. }\end{array}$ \\
\hline & R178 & Inappropriate planning of Forecast Communiqué Divisions \\
\hline W32 & $\mathrm{R} 179$ & Examiner doesn't bargain the excellence difficulties \\
\hline & R180 & Self-test problematic is not appropriate corrected \\
\hline W33 & R181 & Manufacture unit self-test is not thoughtful \\
\hline & R182 & Receiving division does not achieve the consistent responsibilities \\
\hline & R183 & Manufacture receiving does not license \\
\hline & R184 & The flaw in the method of manufacture receiving is not timely removed \\
\hline & R185 & $\begin{array}{l}\text { Practical evidence reported to the communication division does not encounter } \\
\text { all the necessities }\end{array}$ \\
\hline & R186 & Appointing plan is not succumbed timely and precise \\
\hline & $\mathrm{R} 187$ & Manuscript evidence is absent \\
\hline W34 & R188 & Work which desires to be executed is uncompleted \\
\hline W35 & R189 & Data transmission surpasses the prearranged time \\
\hline & R190 & Data transported is imperfect or non-standard \\
\hline W36 & R191 & Manufacturing Alteration Credential is imperfect or unusual. \\
\hline & R192 & Sketch inspection precipitate is not consistent \\
\hline & R193 & Manufacture modest groundwork postponements and has oversights \\
\hline
\end{tabular}




\begin{tabular}{lll}
\hline R194 & BOQ groundwork is imprecise \\
R195 & $\begin{array}{l}\text { Disagreement occurred among manufacture administration unit and } \\
\text { manufacture unit. }\end{array}$ \\
R196 & Imperfect financial records evidence \\
R197 & Explanation handover R. \\
R198 & Manufacturing FM and device's plan R \\
R199 & Cash flow difficulties and other endowment RM. \\
R200 & Manufacturing archived data's value has blemishes. \\
R201 & Excellence coincidence occurs after placing into process \\
R202 & Inferior task post-maintenance effort \\
R203 & The time of manufacturing last financial records and endorsement is long. \\
R204 & Task is ailing functioned after placing into process. \\
R205 & Ecological defense, water preservation and other unusual review does not \\
& permit \\
R206 & The agreement plaid is not thoughtful. \\
R207 & Examination accounts of covered works are imperfect \\
R208 & Project Modification Credential is not consistent \\
R209 & Manufacturing amount's check is not correct \\
R210 & Pricing not harmonies with the agreement footings. \\
R211 & Fee control mistakes \\
R212 & The examiner is not in conformism with the excellence normal \\
R213 & Task image data does not encounter the necessities \\
R214 & Excellence chance occurs after placing into process. \\
R215 & Ecological defense, water conservation and other unusual review does not \\
permit.
\end{tabular}

\section{References}

[1] Gu, Y.G.; Luo, Z.; Shan, B.G. Outlook 2013 of Power Supply and Demand in China and Related Suggestions. Electr. Power 2013, 46, 7-10.

[2] Lin, W.B.; Chen, B.; Yu, Y.S. Research on Rorecasting Electricity Demand oR the12th Rive-year and 2020. China Popul. Resour. Environ. 2011, 21, 1-6.

[3] Merna, T.; Al-Thani, F.F. Corporate Risk Management; John Wiley \& Sons Inc.: Hoboken, NJ, USA, 2008.

[4] Chapman, C. Project risk analysis and management-the PRAM generic process. Int. $J$. Proj. Manag. 1997, 15, 273-281.

[5] Institute of Risk Management. A Risk Management; Standard Institute of Risk Management: London, UK, 2002.

[6] Project Management Institute. A Guide to the Project Management Body of Knowledge; Project Management Institute Standards Committee: Philadelphia, PA, USA, 2008.

[7] Edwards, P.J.; Bowen, P.A. Risk and risk management in construction: A review and future directions for research. Eng. Constr. Archit. Manag. 1998, 5, 339-349.

[8] Zhou, L.; Vasconcelos, A.; Numes, M. Supporting decision making in risk 
management through an evidence-based information systems project risk checklist. Inf. Manag. Comput. Secur. 2008, 16, 166-186.

[9] Tah, J.H.M.; Thorpe, A.; McCaffer, R. Contactor project risks contingency allocation using linguistic approximation. Comput. Syst. Eng. 1993, 4, 281-293.

[10] Wirba, E.N.; Tah, J.H.M.; Howes, R. Risk interdependencies and natural language computations.

[11] J. Eng. Constr. Archit. Manag. 1996, 3, 251-269.

[12] Liu, J.Y.; Wang, Z.F. Non-additivity analysis on scheduling risks based on Bayesain networks.

[13] Syst. Eng.-Theory Pract. 2011, 31, 1517-1523.

[14] Liu, J.Y. Correlation analysis of scheduling risks based on BN-CPM. J. Hydroelectr. Eng. 2011,

[15] 30, 199-203.

[16] Li, C.B.; Lu, G.S.; Li, P.; Zhang, C.S. Grid Construction Project Schedule Risk Analysis Based on Rough Set Theory. East China Electr. Power 2012, 40, 1325-1327.

[17] Jiang Z.L.; Wang D.Y.; Liu X.J. Study on the risk analysis and benefit sharing in BT construction project. J. Hunan Univ. (Nat. Sci.) 2012, 39, 89-92.

[18] Wang, Z.Q.; Liu, Y.J.; Yu, J.R. Applying research of SCERT on risk analysis and management of large project. China Soft Sci. 2002, 7, 105-108.

[19] Ahmed, A.; Kayis, B.; Amornsawadwatana, S. A review of techniques for risk management in projects. Benchmarking 2007, 14, 22-36.

[20] Nieto-Morote, A.; Ruz-Vila, F. A fuzzy approach to construction project risk assessment. Int. J. Project Manag. 2011, 29, 220-231.

[21] Zhao, H.; Li, Y.J.; Song, T. Study on engineering project risk management based on Bayesian network. J. Shenyang Univ. Technol.: Soc. Sci. Ed. 2008, 1, 239-244.

[22] Liu, J.Y. Bayesian network inference on risks of construction schedule cost[C]. In Proceedings of the 2010 International Conference of Information Science and Management Engineering, Xi'an, China, 7-8 August 2010; Volume 2, pp. 15-18.

[23] Taroun, A. Towards a better modeling and assessment of construction risk: Insights from a literature review. Int. J. Project Manag. 2014, 32, 101-115.

[24] Williams, T. The two-dimensionality of project risk. Int. J. Proj. Manag. 1996, 14, $185-186$.

[25] Jannadi, O.A.; Almishari, S. Risk assessment in construction. J. Constr. Eng. Manag. 2003, 129,492.

[26] Aven, T.; Vinnem, J.; Wiencke, H. A decision framework for risk management, with application to the offshore oil and gas industry. Reliab. Eng. Syst. Saf. 2007, 92, 433448.

[27] Cagno, E.; Caron, F.; Mancini, M. A multi-dimensional analysis of major risks in complex projects. Risk Manag. 2007, 9, 1-18.

[28] Cioffi, D.F.; Khamooshi, H. A practical method of determining project risk contingency budgets.

[29] J. Oper. Res. Soc. 2009, 60, 565-571.

[30] Fan, C.F.; Yu, Y.C. BBN-based software project risk management. J. Syst. Softw. 2004, 73,193-203. 
[31] Molenaar, K.R. Programmatic cost risk analysis for highway megaprojects. J. Constr. Eng. Manag. 2005, 131, 343.

[32] Saaty, T.L. Analytic hierarchy process. In Encyclopedia of Biostatistics; John Wiley \& Sons Inc.: Hoboken, NJ, USA, 1980.

[33] Tah, J.; Carr, V. A proposal for construction project risk assessment using fuzzy logic. Constr. Manag. Econ. 2000, 18, 491-500.

[34] Duan, B.Q. Comprehensive risk assessment model of complex product systems innovation based on Fuzzy AHP. J. Tongji Univ. (Nat. Sci.) 2008, 36, 23-26.

[35] Xiao, L.; Qi, Y.; Li, Q.M. Information security risk assessment based on AHP and fuzzy comprehensive evaluation. Comput. Eng. Appl. 2009, 45, 89-91.

[36] Zhang, X.S.; Wang, S.F.; Guo, X.L. Research on evaluation risk of power market based on Monte Carlo simulation. Relay 2007, 35, 66-73.

[37] Wang, T.H.; Song, Y.X.; Song, CH.Q. Risk evaluation of wartime equipment supply chain based on TOPSIS method with fuzzy ameliorated Entropy Weight. Comput. Digit. Eng. 2012, 40, 101-106.

[38] Guan, S.X.; Zhang, Y. Credit risk evaluation in commercial bands using TOPSIS model based on Entropy Weights. J. Inf. 2008, 27, 59-65.

[39] Liu, H.L.; Zhou, Y.N.; Zheng, L. The process variance analysis model distinguishing the critical and non-critical path. Constr. Manag. Modern. 2009, 23, 502-504.

[40] Tian, Z.X.; Ye, J.; Zhang, X. Project object cost and time control research. J. Beijing Univ. Aeronaut. 2001, 14, 37-41.

[41] Zou, P.X.W.; Zhang, G.M.; Wang, J.Y. Understanding the key risks in construction projects in China. Int. J. Proj. Manag. 2007, 25, 601-614.

[42] Sara, M.S.; Amaya, P.E.; Angel, M.E.L.; Pedro, V. Project risk management methodology for small firms. Int. J. Proj. Manag. 2013, 32, 327-340.

[43] Flanagan, R.; Norman, G. Risk Management and Construction; Blackwell Science Pty Ltd.: Victoria, Australia, 1993.

[44] Wang, S.Q.; Tiong, R.L.K.; Ting, S.K.; Ashley, D. Evaluation and management of foreign exchange andrevenue risks in China's BOT projects. Constr. Manag. Econ. 2008, 18, 197-207.

[45] Baker, W.; Reid, H. Identifying and Managing Risk; Pearson Education: French Forest, Australia, 2005.

[46] Shen, L.Y.; Wu, G.W.C.; Ng, C.S.K. Risk assessment for construction joint ventures in China.

[47] J. Constr. Eng. Manag. 2001, 127, 76-81. 